Published in final edited form as:

Inorg Chem. 2019 November 18; 58(22): 15659-15670. doi:10.1021/acs.inorgchem.9b02780.

\title{
ATP7B Binds Ruthenium(II) $p$-Cymene Half-Sandwich Complexes: Role of Steric Hindrance and Ru-I Coordination in Rescuing the Sequestration
}

\author{
Kallol Purkait ${ }^{\# \dagger}$, Ruturaj ${ }^{\# \ddagger}$, Arindam Mukherjee ${ }^{\star}, \dagger, \|$, Arnab Gupta ${ }^{*}, \ddagger$ \\ tDepartment of Chemical Sciences, Indian Institute of Science Education and Research (IISER) \\ Kolkata, Mohanpur Campus, Mohanpur 741246, India \\ FDepartment of Biological Sciences, Indian Institute of Science Education and Research (IISER) \\ Kolkata, Mohanpur Campus, Mohanpur 741246, India \\ "Centre for Advanced Functional Materials, Indian Institute of Science Education and Research \\ (IISER) Kolkata, Mohanpur Campus, Mohanpur 741246, India \\ \# These authors contributed equally to this work.
}

\section{Abstract}

Ruthenium(II/III) complexes are predicted to be effcient alternatives to platinum drug-resistant cancers but have never been investigated for sequestration and efflux by Cu-ATPases (ATP7A or ATP7B) overexpressed in resistant cancer cells, although a major cause of platinum drug resistance is found to be sequestration of platinum chemotherapeutic agents by thiol donors glutathione (GSH) or the Cys-X-X-Cys (CXXC) motifs in the Cu-ATPases in cytosol. Here, we show for the first time that ATP7B effciently sequesters ruthenium(II) $\eta^{6}$ - $p$-cymene complexes. We present seven complexes, $\left[\mathrm{Ru}^{\mathrm{II}}\left(\eta^{6}-p\right.\right.$-cym $\left.)(\mathrm{L}) \mathrm{X}\right]\left(\mathrm{PF}_{6}\right)(\mathbf{1}-\mathbf{7} ; \mathrm{L}=\mathrm{L} 1-\mathrm{L} 3, \mathrm{X}=\mathrm{Cl}, \mathrm{Br}$, and $\mathrm{I})$, out of which two resists deactivation by the cellular thiol, glutathione (GSH). The results show that $\mathrm{Ru}$ - I coordination and a moderate steric factor increase resistance to GSH and the CXXC motif. Ru${ }^{\mathrm{II}}$ -I-coordinated $\mathbf{3}$ and $\mathbf{7}$ showed resistance to sequestration by ATP7B. 3 displays highest resistance against GSH and does not trigger ATP7B trafficking in the liver cancer cell line. It escapes ATP7B-mediated sequestration and triggers apoptosis. Thus, with a suitable bidentate ligand and iodido leaving group, $\mathrm{Ru}^{\mathrm{II}}\left(\eta^{6}-p\right.$-cym) complexes may display strong kinetic inertness to inhibit the ATP7B detoxification pathway. Inductively coupled plasma mass spectrometry data show higher retention of $\mathbf{3}$ and $\mathbf{7}$ inside the cell with time compared to 4, supporting ATP7B-mediated sequestration.

*a.mukherjee@iiserkol.ac.in. (A.M.). arnab.gupta@iiserkol.ac.in (A.G.).

Accession Codes

CCDC 1916899, 1916900, and 1954365 contain the supplementary crystallographic data for this paper. These data can be obtained free of charge via www.ccdc.cam.ac.uk/data_request/cif, or by emailing data_request@ccdc.cam.ac.uk, or by contacting The Cambridge Crystallographic Data Centre, 12 Union Road, Cambridge CB2 1EZ, UK; fax: +44 1223336033.

Notes

The authors declare no competing financial interest. 


\section{Introduction}

The resistance of cancers against chemotherapeutics (viz., cisplatin, carboplatin, oxaliplatin) has been assigned to various factors with major emphasis on thiol-donor-based binding and deactivation of metal-based anticancer agents. ${ }^{1-14}$ Cellular reducing agent glutathione (GSH) and efflux proteins (viz., ABCC1/GS-X pump and ATPases) are thiol-based sequestering agents that bind to the metal complexes and lead to their exportation from cells. 13,15-17 Detailed studies have shown that the export ATPases (ATP7A and ATP7B) are pivotal in imparting resistance toward platinum-based chemotherapy. ${ }^{15}$ ATP7A and ATP7B sequester the platinum drugs with their thiol motif Cys-X-X-Cys (CXXC) ${ }^{18-20}$ Previous studies have shown that downregulation of ATP7B leads to higher efficacy of cisplatin treatment. ${ }^{21}$ The deactivation may be attributed to the soft nature of the thiol donors making platinum(II) a putative binding target similar to copper(I). Thus, in response to cisplatin accumulation in cancer cells, the ATPases (ATP7A or ATP7B) mobilize from the Golgi toward the plasma membrane by binding cisplatin to their thiol-containing motifs MXCXXC. ${ }^{22-24}$ Cisplatin transport by the overexpression of ATP7B was originally reported by Komatsu et al. ${ }^{19}$ in a cisplatin-resistant prostate carcinoma cell, which was later supported by multiple studies in this area. ${ }^{25-30}$ It is known that ATP7A, which at the binding site is similar to ATP7B, does not bind to carboplatin or oxaliplatin as much as it does to cisplatin. ${ }^{31,32}$ Interestingly, cisplatin may be just vesicularized upon sequestration by ATP7A or ATP7B, leading to higher accumulation in cancer cells and a loss of efficacy. ${ }^{33}$ The loss of efficacy is attributed to the effective sequestration by ATP7A or ATP7B in compartments (viz., vesicles), thus cutting their access to desired targets. The situation worsens as platinum(II) drugs increase the expression of ATP7A/ATP7B. ${ }^{18,31,32}$

Ruthenium(II) $p$-cymene half-sandwich complexes, because of their potential anticancer properties, are becoming promising alternatives to platinum(II). ${ }^{4-7,10,11,34-42}$ It was earlier shown that certain ruthenium(II) $p$-cymene complexes are susceptible to sequestration and efflux by phosphoglyco-protein and multidrug (associated) protein $2 .{ }^{43}$ However, it remains unknown whether ruthenium(II) complexes would also be sequestered by $\mathrm{Cu}$-ATPases, which are known to transport platinum(II) drugs. The charge/radius ratio is suggestive that copper(I) (ratio, 1.6) should have the highest affinity, and similar to platinum(II) (ratio, 2.1), ruthenium(II) (ratio, 2.0) should also be sequestered by Cu-ATPases. Ruthenium(II) has emerged as the metal of choice for its higher kinetic inertness, alternate non-DNA targets, and effectiveness against platinum(II)-resistant cancers with an additional capability of prohibiting metastasis and angiogenesis. ${ }^{4,44-50}$ Because sequestration of platinum or copper involves the CXXC motif, we investigated whether ruthenium-(II)-based complexes are also subjected to sequestration by ATP7B. Our motivation was also to rescue the ruthenium(II) $p$ cymene complexes from sequestration using a suitable ligand and hence alleviating drug resistance.

The binding motifs in ATP7A or ATP7B involve thiol donors (CXXC), $51,15,52$ and through our earlier investigations, we made ruthenium(II) $p$-cymene complexes that were resistant to thiol binding because of the presence of steric hindrance or iodido as the leaving group. ${ }^{53,54}$ Earlier reports on the ruthenium iodido complexes show that the ruthenium(II) $p$-cymene 
complexes of bidentate carrier ligands with an iodido leaving group may render higher stability ${ }^{55-57}$ and better resistance to $\mathrm{GSH}^{58}$ and may alter the pathways of cytotoxicity. ${ }^{59,60}$

Hence, we chose to investigate the response of ATP7B toward ruthenium(II) $p$-cymene complexes with variation in the steric hindrance and halide ligand (Figure 1). The choice is governed by an established resistance to GSH through our earlier work. ${ }^{53,54,61}$

\section{Experimental Section}

\section{Materials and Methods}

All complexes and ligands have been synthesized using dried/distilled solvents. The purification of solvents was done as mentioned in the literature. ${ }^{62}$ Chemicals, used for synthesis, were procured from Sigma-Aldrich, Merck, or Spectrochem, except ruthenium(III) chloride, which was from Precious Metal Online (Australia). 3-(4,5Dimethylthiazol-2-yl)-2,5-diphenyltetrazolium bromide [MTT] (USB) and other cell growth media and their supplements (Gibco), reduced L-glutathione (GSH; Aldrich), were used for experiment. $\mathrm{Ru}_{2}{ }^{\mathrm{II}}\left(\eta^{6}-p \text {-cym }\right)_{2}(\mathrm{Cl})_{4}$ was synthesized as per standard literature procedure. ${ }^{63}$ Ruthenium bromido and iodido metal precursors were synthesized from $\left[\mathrm{Ru}_{2}\left(\eta^{6}-p\right.\right.$ cym $)_{2} \mathrm{Cl}_{4}$ ] using a literature-reported procedure. ${ }^{58}$ For spectroscopy, only spectroscopygrade solvents are used, and the $99.9 \%$ deuterated NMR solvents were purchased from Cambridge Isotope Laboratories, Inc. A Cary 300 UV-vis spectrophotometer was used for all UV-vis absorption experiments. Fourier transform infrared (FT-IR) spectra were recorded on a PerkinElmer Spectrum RX I spectrometer in the solid state using $\mathrm{KBr}$ pellets. All types of NMR spectra were recorded by either a JEOL ECS $400 \mathrm{MHz}$ or a Bruker Avance III $500 \mathrm{MHz}$ spectrometer at $25^{\circ} \mathrm{C}$, and the values are reported in parts per million. Elemental analysis for bulk purities was measured by a PerkinElmer 2400 series II CHNS/O analyzer. Electrospray ionization mass spectrometry (ESI-MS) spectra were recorded in positive mode using a maXis impact (Bruker) mass spectrometer. The synthesized complexes were dried in a vacuum and stored in desiccators under a $\mathrm{N}_{2}$ atmosphere. The synthetic procedures of L1-L3 and complexes 1, 4, and $\mathbf{7}$ were recently reported by our group and hence not described here. ${ }^{53,54,61}$ Neutral red (NR) assay was performed using the assay kit protocol (TOX-4, Sigma-Aldrich).

\section{General Synthetic Method for Complexes 2, 3, 5, and 6}

Complexes 2, 3, 5, and $\mathbf{6}$ were synthesized by the following general procedure. A total of 2.2 equiv of ligand was allowed to react with 1 equiv of $\left[\mathrm{Ru}_{2}{ }_{2}\left(\eta^{6}-p \text {-cym }\right)_{2}(\mathrm{X})_{4}\right](\mathrm{X}=\mathrm{Br}$ or I $)$ in methanol for $10 \mathrm{~h}$ at $25^{\circ} \mathrm{C}$ in the dark. Then 2 equiv of $\mathrm{NH}_{4} \mathrm{PF}_{6}$ was added to the reaction mixture. The evaporation of methanol from the reaction mixture gave a solid mass, which was washed several times with diethyl ether to remove excess ligand. Further the solid mass was dissolved in dichloromethane and filtered to remove excess $\mathrm{NH}_{4} \mathrm{PF}_{6}$. The analytically pure complexes were stored in a desiccator at $4-10^{\circ} \mathrm{C}$.

Complex 2-Yield: 68\%. Anal. Calcd for $\mathrm{C}_{20} \mathrm{H}_{23} \mathrm{BrF}_{6} \mathrm{~N}_{3} \mathrm{PRu}$ : C, 38.05; H, 3.67; N, 6.66. Found: C, 38.19; H, 3.60; N, 6.68. Mp: $148{ }^{\circ} \mathrm{C} .{ }^{1} \mathrm{H}$ NMR (400 MHz, DMSO- $d_{6}, 25{ }^{\circ} \mathrm{C}$ ): $\delta$ $8.44(\mathrm{~s}, 1 \mathrm{H}, \mathrm{CH}=\mathrm{N}), 8.14(\mathrm{~s}, 1 \mathrm{H}, \mathrm{Imi}-\mathrm{H}), 7.84(\mathrm{~s}, 1 \mathrm{H}, \mathrm{Imi}-\mathrm{H}), 7.78$ (d, 2H, $J=7.6 \mathrm{~Hz}, \mathrm{Ar}$ 
$-\mathrm{H}), 7.59(\mathrm{~d}, 2 \mathrm{H}, J=6.9 \mathrm{~Hz}, \mathrm{Ar}-\mathrm{H}), 7.53(\mathrm{t}, 1 \mathrm{H}, J=6.9 \mathrm{~Hz}, \mathrm{Ar}-\mathrm{H}), 5.97(\mathrm{~d}, 1 \mathrm{H}, J=6.1 \mathrm{~Hz}$, $p$-cym-H), $5.66(\mathrm{~d}, 1 \mathrm{H}, J=5.32 \mathrm{~Hz}, p$-cym-H), $5.59(\mathrm{~d}, 1 \mathrm{H}, J=5.8 \mathrm{~Hz}, p$-cym-H), $5.48(\mathrm{~d}$, $1 \mathrm{H}, J=6.12 \mathrm{~Hz}, p$-cym-H), 2.12-2.21 (m, 4H, $\mathrm{Pr}-\mathrm{CH}$ and $\left.\mathrm{CH}_{3}\right), 1.00(\mathrm{~d}, 3 \mathrm{H}, J=6.9 \mathrm{~Hz}$, $\left.\mathrm{CH}_{3}\right), 0.95$ (d, $3 \mathrm{H}, J=6.9 \mathrm{~Hz}, \mathrm{CH}_{3}$ ) (Figure S1). ${ }^{13} \mathrm{C}$ NMR: $\left(100 \mathrm{MHz}\right.$, DMSO- $d_{6}, 25{ }^{\circ} \mathrm{C}$ ): $\delta 154.7,152.1,146.1,134.1,129.3,129.1,124.1,122.7,104.4,100.6,85.0,84.8,83.6,83.5$, 30.6, 21.9, 21.2, 18.7 (Figure S2). ESI-HRMS [methanol (calcd)]: $\mathrm{m} / z 486.0145$ (486.0113) $\left[\mathrm{C}_{20} \mathrm{H}_{23} \mathrm{~N}_{3} \mathrm{RuBr}\right]^{+}$. FT-IR (KBr pellets, $\mathrm{cm}^{-1}$ ): 3390, 2967, 1627, 1441, 845. UV-vis $\left[\mathrm{CH}_{3} \mathrm{OH} ; \lambda_{\max }, \mathrm{nm}\left(\varepsilon, \mathrm{dm}^{3} \mathrm{~mol}^{-1} \mathrm{~cm}^{-1}\right)\right]: 324$ (11862), 372 (12176).

Complex 3-Yield: 54\%. Anal. Calcd for $\mathrm{C}_{20} \mathrm{H}_{23} \mathrm{IF}_{6} \mathrm{~N}_{3} \mathrm{PRu}$ : C, 35.41; H, 3.42; N, 6.19. Found: C, 35.57; H, 3.34; N, 6.07. Mp: $91{ }^{\circ} \mathrm{C}(\mathrm{dec}) .{ }^{1} \mathrm{H}$ NMR (400 MHz, DMSO- $d_{6}, 25{ }^{\circ} \mathrm{C}$ ): $\delta 8.40(\mathrm{~s}, 1 \mathrm{H}, \mathrm{CH}=\mathrm{N}), 8.12(\mathrm{~s}, 1 \mathrm{H}, \mathrm{Imi}-\mathrm{H}), 7.84(\mathrm{~s}, 1 \mathrm{H}, \mathrm{Imi}-\mathrm{H}), 7.80(\mathrm{~d}, 2 \mathrm{H}, J=8.0 \mathrm{~Hz}$, $\mathrm{Ar}-\mathrm{H}), 7.51-7.60(\mathrm{~m}, 3 \mathrm{H}, \mathrm{Ar}-\mathrm{H}), 5.92(\mathrm{~d}, 1 \mathrm{H}, J=6.1 \mathrm{~Hz}, p$-cym-H), $5.68(\mathrm{~d}, 1 \mathrm{H}, J=6.1$ $\mathrm{Hz}, p$-cym-H), 5.62 (d, $1 \mathrm{H}, J=6.1 \mathrm{~Hz}, p$-cym-H), 5.48 (d, $1 \mathrm{H}, J=6.1 \mathrm{~Hz}, p$-cym-H), 2.58 $(\mathrm{m}, 1 \mathrm{H}, \mathrm{Ir}-\mathrm{CH}), 2.25$ (s, 3H, p-cym- $\left.\mathrm{CH}_{3}\right), 1.01\left(\mathrm{~d}, 3 \mathrm{H}, J=6.8 \mathrm{~Hz}, \mathrm{CH}_{3}\right), 0.95(\mathrm{~d}, 3 \mathrm{H}, J=$ $6.9 \mathrm{~Hz}, \mathrm{CH}_{3}$ ) (Figure S3). ${ }^{13} \mathrm{C}$ NMR $\left(100 \mathrm{MHz}\right.$, DMSO- $d_{6}, 25^{\circ} \mathrm{C}$ ): $\delta 154.4,152.3,145.8$, $134.7,129.3,129.2,124.2,123.2,10^{5} .9,100.0,85.5,84.4,84.1,83.5,31.0,22.0,21.2,19.6$ (Figure S4). ESI-HRMS [methanol (calcd)]: $\mathrm{m} / z$ 533.9961 (533.9975) $\left[\mathrm{C}_{20} \mathrm{H}_{23} \mathrm{~N}_{3} \mathrm{RuI}\right]^{+}$. FTIR ( $\mathrm{KBr}$ pellets, $\left.\mathrm{cm}^{-1}\right): 3393,2964,1629,1437,844$. UV-vis $\left[\mathrm{CH}_{3} \mathrm{OH} ; \lambda_{\max }, \mathrm{nm}\left(\varepsilon, \mathrm{dm}^{3}\right.\right.$ $\left.\mathrm{mol}^{-1} \mathrm{~cm}^{-1}\right)$ ]: 219 (29039), 322 (11908), 375 (8188).

Complex 5-Yield: 73\%. Anal. Calcd for $\mathrm{C}_{26} \mathrm{H}_{35} \mathrm{BrF}_{6} \mathrm{~N}_{3} \mathrm{PRu}$ : C, 43.64; H, 4.93; N, 5.87. Found: C, 43.74; $\mathrm{H}, 4.91 ; \mathrm{N}, 5.83$. Mp: $132{ }^{\circ} \mathrm{C} .{ }^{1} \mathrm{H}$ NMR (400 MHz, DMSO- $d_{6}, 25{ }^{\circ} \mathrm{C}$ ): $\delta$ $8.52(\mathrm{~s}, 1 \mathrm{H}, \mathrm{CH}=\mathrm{N}), 8.21(\mathrm{~s}, 1 \mathrm{H}, \mathrm{Imi}-\mathrm{H}), 7.85(\mathrm{~s}, 1 \mathrm{H}, \mathrm{Imi}-\mathrm{H}), 7.45(\mathrm{~d}, 2 \mathrm{H}, J=6.1 \mathrm{~Hz}, \mathrm{Ar}$ $-\mathrm{H}), 7.37(\mathrm{t}, 1 \mathrm{H}, J=5.4 \mathrm{~Hz}, \mathrm{Ar}-\mathrm{H}), 5.85(\mathrm{~d}, 1 \mathrm{H}, J=6.1 \mathrm{~Hz}, p$-cym-H), $5.61(\mathrm{~d}, 1 \mathrm{H}, J=$ $6.12 \mathrm{~Hz}, p$-cym-H), 5.44 (d, $1 \mathrm{H}, J=6.1 \mathrm{~Hz}, p$-cym-H), 5.21 (d, $1 \mathrm{H}, J=6.1 \mathrm{~Hz}, p$-cym-H), $3.83(\mathrm{~m}, 1 \mathrm{H}, i \mathrm{Pr}-\mathrm{CH}), 2.67(\mathrm{~m}, 1 \mathrm{H}, i \mathrm{Pr}-\mathrm{CH}), 2.55(\mathrm{~m}, 1 \mathrm{H}, i \mathrm{Pr}-\mathrm{CH}), 2.12(\mathrm{~s}, 3 \mathrm{H}, p$-cym $\left.-\mathrm{CH}_{3}\right), 1.42\left(\mathrm{~d}, 3 \mathrm{H}, J=6.8 \mathrm{~Hz}, \mathrm{CH}_{3}\right), 1.22\left(\mathrm{~d}, 3 \mathrm{H}, J=6.9 \mathrm{~Hz}, \mathrm{CH}_{3}\right), 1.10(\mathrm{~d}, 3 \mathrm{H}, J=6.1$ $\left.\mathrm{Hz}, \mathrm{CH}_{3}\right), 1.06\left(\mathrm{~d}, 3 \mathrm{H}, J=6.9 \mathrm{~Hz}, \mathrm{CH}_{3}\right), 1.02\left(\mathrm{~d}, 3 \mathrm{H}, J=6.9 \mathrm{~Hz}, \mathrm{CH}_{3}\right), 0.82(\mathrm{~d}, 3 \mathrm{H}, J=6.9$ $\mathrm{Hz}, \mathrm{CH}_{3}$ ) (Figure S5). ${ }^{13} \mathrm{C}$ NMR $\left(125 \mathrm{MHz}\right.$, DMSO- $\left.d_{6}, 25{ }^{\circ} \mathrm{C}\right): \delta 159.6,148.2,141.1$, $139.7,134.2,128.5,124.9,124.8,124.2,124.1,105.3,99.2,85.9,84.5,82.8,82.4,30.3$, 27.6, 27.5, 26.6, 25.7, 23.0, 22.1, 21.7, 21.1, 18.2 (Figure S6). ESI-HRMS [methanol (calcd)]: $\mathrm{m} / z$ 570.1034 (570.1052) $\left[\mathrm{C}_{26} \mathrm{H}_{35} \mathrm{~N}_{3} \mathrm{RuBr}\right]^{+}$. FT-IR (KBr pellets, $\mathrm{cm}^{-1}$ ): 3436, 2965, 1634, 1436, 845. UV-vis [ $\left.\mathrm{CH}_{3} \mathrm{OH} ; \lambda_{\max }, \mathrm{nm}\left(\varepsilon, \mathrm{dm}^{3} \mathrm{~mol}^{-1} \mathrm{~cm}^{-1}\right)\right]: 307$ (7063), 373 (3509).

Complex 6-Yield: 67\%. Anal. Calcd for $\mathrm{C}_{26} \mathrm{H}_{35} \mathrm{IF}_{6} \mathrm{~N}_{3} \mathrm{PRu}$ : C, 40.95; H, 4.63; N, 5.51. Found: C, 41.13; H, 4.62; N, 5.53. Mp: $185^{\circ} \mathrm{C}(\mathrm{dec}) .{ }^{1} \mathrm{H}$ NMR (500 MHz, DMSO- $d_{6}, 25$ $\left.{ }^{\circ} \mathrm{C}\right): \delta 8.49(\mathrm{~s}, 1 \mathrm{H}, \mathrm{CH}=\mathrm{N}), 8.23(\mathrm{~s}, 1 \mathrm{H}, \mathrm{Imi}-\mathrm{H}), 7.88(\mathrm{~s}, 1 \mathrm{H}, \mathrm{Imi}-\mathrm{H}), 7.46(\mathrm{~d}, 2 \mathrm{H}, J=4.0$ $\mathrm{Hz}, \mathrm{Ar}-\mathrm{H}), 7.38(\mathrm{t}, 1 \mathrm{H}, J=4.0 \mathrm{~Hz}, \mathrm{Ar}-\mathrm{H}), 5.86(\mathrm{~d}, 1 \mathrm{H}, J=6.1 \mathrm{~Hz}, p$-cym-H), 5.68-5.71 $(\mathrm{m}, 2 \mathrm{H}, p$-cym-H), $5.16(\mathrm{~d}, 1 \mathrm{H}, J=5.4 \mathrm{~Hz}, p$-cym-H), $3.92(\mathrm{~m}, 1 \mathrm{H}, \mathrm{Pr}-\mathrm{CH}), 2.90(\mathrm{~m}, 1 \mathrm{H}$, $\left.{ }_{i} \mathrm{Pr}-\mathrm{CH}\right), 2.70\left(\mathrm{~m}, 1 \mathrm{H}, \imath_{\mathrm{Pr}}-\mathrm{CH}\right), 2.18(\mathrm{~s}, 3 \mathrm{H}, p$-cym-CH$), 1.43\left(\mathrm{~d}, 3 \mathrm{H}, J=6.5 \mathrm{~Hz}, \mathrm{CH}_{3}\right.$ ), $1.22\left(\mathrm{~d}, 3 \mathrm{H}, J=6.5 \mathrm{~Hz}, \mathrm{CH}_{3}\right), 1.17$ (d, $\left.3 \mathrm{H}, J=6.5 \mathrm{~Hz}, \mathrm{CH}_{3}\right), 1.07$ (d, $3 \mathrm{H}, J=6.7 \mathrm{~Hz}, \mathrm{CH}_{3}$ ), $1.01\left(\mathrm{~d}, 3 \mathrm{H}, J=6.7 \mathrm{~Hz}, \mathrm{CH}_{3}\right), 0.83\left(\mathrm{~d}, 3 \mathrm{H}, J=6.4 \mathrm{~Hz}, \mathrm{CH}_{3}\right.$ ) (Figure $\left.\mathrm{S} 7\right) .{ }^{13} \mathrm{C} \mathrm{NMR}(125$ MHz, DMSO- $\left.d_{6}, 25^{\circ} \mathrm{C}\right): \delta 159.3,148.4,145.5,140.9,139.7,136.9,135.1,128.6,124.9$, 
124.2, 106.3, 98.5, 86.1, 85.1, 83.1, 82.2, 30.4, 28.6, 27.5, 25.6, 23.4, 23.0, 22.3, 21.6, 20.9, 18.8 (Figure S8). ESI-HRMS [methanol (calcd)]: $\mathrm{m} / z 618.0907$ (618.0914) $\left[\mathrm{C}_{26} \mathrm{H}_{35} \mathrm{~N}_{3} \mathrm{RuI}\right.$ ] + . FT-IR $\left(\mathrm{KBr}\right.$ pellets, $\left.\mathrm{cm}^{-1}\right): 3435,2964,1637,1438,848$. UV-vis $\left[\mathrm{CH}_{3} \mathrm{OH} ; \lambda_{\max }, \mathrm{nm}(\varepsilon\right.$, $\left.\mathrm{dm}^{3} \mathrm{~mol}^{-1} \mathrm{~cm}^{-1}\right)$ ]: 242 (29395), 288 (19586), 317 (16799), 373 (6953).

\section{X-ray Crystallography}

Suitable single crystals of $\mathbf{2 , 5}$, and $\mathbf{6}$ were obtained from dichloromethane-hexane layering at $4{ }^{\circ} \mathrm{C}$ and mounted on a goniometer under a flow of nitrogen. Data were collected at $100 \mathrm{~K}$ with a monochromatic Mo Ka source $(\lambda=0.71073 \AA$ ) for complexes 2 and $\mathbf{5}$. Because of the unavailability of the Mo Ka source, a monochromatic $\mathrm{Cu} \mathrm{Ka}$ source $(\lambda=1.5406 \AA)$ was used to collect single-crystal X-ray diffraction (SCXRD) data for complex $\mathbf{6}$. All of the crystal data were collected using a SuperNova, Dual, $\mathrm{Cu}$ at zero, Eos diffractometer (Agilent). Data collection and data reduction were performed using CrysAlisPro, version 1.171.37.31 (Agilent Technologies; release 14-01-2014 CrysAlis171.NET), software. Single-crystal structures were solved with the Superflip ${ }^{64}$ or ShleXT structure solution program using Charge flipping or Intrinsic phasing method, respectively. All the structures were refined with the ShelXL refinement package ${ }^{65}$ using least-squares minimization, in Olex $2 .{ }^{66}$ Refinement with anisotropic displacement parameters was used for all nonhydrogen atoms, and the hydrogen atoms were calculated and fixed using the provisions of ShelXL after hybridization of all non-hydrogen atoms. ${ }^{67}$ The quality of the single crystal of 6 was relatively poor, leading to multiple residual electron densities near the heavy atoms in the asymmetric unit and poor refinement parameters. The details are described in the CIF file of $\mathbf{6}$. The CCDC numbers are 1916899, 1916900, and 1954365 for 2, 5, and $\mathbf{6}$, respectively.

\section{Stability Study}

The stability of all of the complexes (1-6) in extracellular chloride concentration was monitored by ESI-MS, where the complexes were dissolved and incubated in 2:8 (v/v) methanol-5 mM phosphate buffer ( $\mathrm{pH}$ 7.4) containing $110 \mathrm{mM}$ chloride concentration at 37 ${ }^{\circ} \mathrm{C}$. Finally, the spectra were recorded at $0.5,4$, and $24 \mathrm{~h}$. The spectra were simulated in Bruker Daltonics software.

\section{L-GSH Binding Study}

The L-GSH binding study was monitored by ESI-MS, where complexes 1-6 were incubated with 25 equiv of GSH in 2:8 (v/v) methanol-5 mM phosphate buffer ( $\mathrm{pH} 7.4$ ) containing 4 $\mathrm{mM}$ chloride concentration at $37^{\circ} \mathrm{C}$. The spectra were recorded at two time points, 0.5 and $24 \mathrm{~h}$. The spectra were finally simulated in Bruker Daltonics software.

\section{Cell Lines and Culture}

The human metastatic breast adenocarcinoma (MDA-MB-231), human pancreatic carcinoma (MiaPaCa-2) and hepatocarcinoma (HepG2) cells were obtained from the National Centre for Cell Science, Pune, India. The MiaPaCa-2 cells were maintained in Dulbecco's modified Eagle medium (DMEM), HepG2 was grown in a minimum essential medium, and MDAMB-231 was maintained in a DMEM/F12 medium with a supplement of $10 \%$ fetal bovine 
serum (FBS; Gibco) and $1 \times$ antibiotic-antimitotic solutions. The standard condition, i.e., $95 \%$ humidity and $5 \% \mathrm{CO}_{2}$ at a temperature of $37{ }^{\circ} \mathrm{C}$, was used for the cell culture.

\section{Cell Viability Assay}

The anticancer activity of the complexes against cancer cells was determined by MTT or NR assay. Briefly, $6 \times 10^{3}$ viable cancer cells were seeded in each well of a 96-well microplate (Nunc) and incubated at $37{ }^{\circ} \mathrm{C}(5 \% \mathrm{CO} 2$ atmosphere). After $48 \mathrm{~h}$ of incubation, the medium was replaced with a fresh one containing the desired concentration of test compounds, where each concentration was loaded in quadruplicate. Dimethyl sulfoxide (DMSO) was used to prepare compound stock solutions and then diluted in a medium quickly such that the percentage of DMSO in each well was $<0.2 \%$. After $48 \mathrm{~h}$ of incubation with the compound solution, the medium was removed and a fresh medium was added, after which $20 \mu \mathrm{L}$ of 1 $\mathrm{mg} \mathrm{mL} \mathrm{mL}^{-1}$ MTT in phosphate-buffered saline (PBS; $\mathrm{pH}$ 7.2) was added to each well and incubated for $4 \mathrm{~h}$ under a humidified $5 \% \mathrm{CO}_{2}$ atmosphere to form formazan crystals in metabolically active cells. The medium was then removed, and $200 \mu \mathrm{L}$ of DMSO was added to each well of the 96-well plate to dissolve the formazan crystals. The absorbance was recorded at $515 \mathrm{~nm}$ using a Spectramax M2 plate reader of Molecular Device, USA. ${ }^{68,69}$ $\mathrm{IC}_{50}$ values were obtained from the plot of percent inhibition versus log [concentration, $\mu \mathrm{M}$ or nM] fitted using nonlinear fitting curves in GraphPad Prism 5. Each of the data represented here is an average of three independent experiments with standard deviation.

\section{Apoptosis Detection: Annexin V-PE/7AAD Assay}

A total of $1 \times 10^{5}$ MDA-MB-231 cells were seeded in a $35 \mathrm{~mm}$ Petri dish under normoxic conditions at $37{ }^{\circ} \mathrm{C}$ and incubated for $48 \mathrm{~h}$. After $48 \mathrm{~h}$ of incubation, the medium was removed and a fresh medium was added containing complex 3 ( $\mathrm{IC}_{50}$ dose, $\left.7.5 \mu \mathrm{M}\right)$. The treated cells were incubated for another $24 \mathrm{~h}$. The treated cells were harvested and washed with $1 \times$ PBS. Finally, the cell pellet was stained using Annexin V-PE and 7AAD as per kit protocol (Annexin V-PE Apoptosis Detection Kit I, BD Pharmingen, catalog no. 559763) and analyzed in a BD Biosciences FACS Calibur flow cytometer.

\section{Detection of Mitochondrial Membrane Depolarization by JC-1}

A total of $1 \times 10^{5}$ MDA-MB-231 cells were seeded in a $35 \mathrm{~mm}$ Petri dish under normoxic condition at $37{ }^{\circ} \mathrm{C}$ and incubated for $48 \mathrm{~h}$. After that, the medium was replenished by a fresh medium containing complex 3 ( $\mathrm{IC}_{50}$ dose, $7.5 \mu \mathrm{M} ; \mathrm{IC}_{25}$ dose, $\left.6.5 \mu \mathrm{M}\right)$ and incubated for another $24 \mathrm{~h}$. The treated cells were harvested and washed with $1 \times$ PBS. Finally, the cell pellet was stained using JC- 1 dye $\left(10 \mu \mathrm{g} \mathrm{mL}^{-1}\right.$ in $10 \%$ FBS containing $\left.1 \times \mathrm{PBS}\right)$. After 30 min of incubation at $37^{\circ} \mathrm{C}$, the JC-1-treated cells were analyzed in a BD Biosciences FACS Calibur flow cytometer.

\section{Real-Time Polymerase Chain Reaction (PCR)}

HepG2 cells were seeded in $60 \mathrm{~mm}$ Petri dishes, and all of the treatments were performed after 70\% confluency. RNA was isolated with a TRIzol reagent (Invitrogen, catalog no. 15596018) method using the provided protocol. The RNA sample was run on gel to check the quality of RNA, and subsequently cDNA was synthesized using a Verso cDNA synthesis 
kit (Thermo Scientific, catalog no. AB1453A) according to the manufacturer's protocol, where an equal amount of RNA was added to each reaction. SYBR green was used from Biorad, and the reaction was performed in an Applied Biosystems 7500 thermocycler with the standard reaction setup. The experiments were performed as per MIQC guidelines.

\section{Western Blot Analysis}

The HepG2 cells were seeded in $60 \mathrm{~mm}$ Petri dishes and treated with compounds after 70\% confluency. For HIF-1 $a$ Western blot, cells were harvested and lysate was prepared by sonication in a RIPA lysis buffer containing $50 \mathrm{mM}$ Tris, $150 \mathrm{mM} \mathrm{NaCl}, \mathrm{pH} 7.4,0.1 \%$ sodium dodecyl sulfate (SDS), $0.5 \%$ sodium deoxycholate, $1 \%$ Triton X-100, $1 \mathrm{mM}$ ethylenediaminetetraacetic acid, and protease inhibitor cocktail (VWR Lifesciences). The whole lysate was centrifuged at $15000 \mathrm{~g}$ for $15 \mathrm{~min}$ at $4{ }^{\circ} \mathrm{C}$ to remove the insoluble fraction. The supernatant was collected and the protein concentration measured using Bradford (Sigma-Aldrich) assay, and equal amounts of the protein solution were loaded in 10\% SDS polyacrylamide gel electrophoresis (SDS-PAGE). Following transfer to a nitrocellulose (Biorad) membrane, HIF-1 $a$ was detected using a mouse anti-HIF-1 $a$ antibody (BD) and horseradish peroxidase (HRP)-conjugated goat antirabbit antibody, and glyceraldehyde 3phosphate dehydrogenase (GAPDH) was used as the loading control to ensure an equal amount of protein in each lane, which was detected by a rabbit anti-GAPDH antibody (BioBharati) and an HRP-conjugated rabbit antimouse antibody.

\section{Immunofluorescence}

The HepG2 cells were seeded in $35 \mathrm{~mm}$ dishes containing glass coverslips. All of the treatments were performed at 70\% confluency. Cells were fixed with $4 \%$ paraformaldehyde after $2 \mathrm{~h}$ of treatment. The cells were washed with PBS and blocked in 3\% bovine serum albumin in PBS with $0.1 \%$ Tween 20 for permeabilization. Incubated with primary antibody rabbit anti-ATP7B (abcam) and mouse anti-Golgin97 (Invitrogen) in 1:400 dilution, followed by washing with PBS and secondary antibody Alexa 488-conjugated donkey antirabbit (Invitrogen) and Alexa 568-conjugated donkey antimouse incubation in 1:1000 dilution. After washing with PBS, the cells were mounted on slides for imaging using Fluoroshield (Merck) with a 4',6-diamidino-2-phenylindole mounting medium. All images were taken by a Leica SP8 confocal microscope with a $63 \times$ oil immersion objective. All of the images were processed using $L A S X$ and ImageJ software.

\section{Cloning of GST-N-ATP7B}

The N-terminal of ATP7B was cloned in pGEX vector (gift from Rahul Das, DBS, IISER Kolkata). In a brief description, the N-terminal was PCR-amplified using GFP-ATP7B ${ }^{70}$ (gift from Hubbard Laboratory, Johns Hopkins University School of Medicine, Baltimore, $\mathrm{MD)}$ as the template and primers:

Forward: CCCTGGGATCCATGCCTGAGCAGGAGAGACAGATC

Reverse: CTCGAGTCGACTTACTTGTGGTCCAAGTGATGAGC 
It was run on a gel and purified using a PureLink Gel extraction kit (Invitrogen, catalog no. K210012) according to the manufacturer's protocol. BamHI-HF (catalog no. R3136S) and SaII-HF (catalog no. R3138S) restriction endonucleases from NEB were used for creating sticky ends. Finally, the digested vector and insert were ligated using a T4 DNA ligase (NEB, catalog no. M0202S). Successful cloning was confirmed after sequencing.

\section{Bacterial DIC Imaging}

BL21 (DE3) Escherischia coli cells were inoculated from an overnight culture in a 1:100 (v/v) ratio into $5 \mathrm{~mL}$ of LB broth (HiMedia) in glass test tubes. They were grown in a BOD incubator for $30 \mathrm{~min}$ to reach the log phase. All of the treatments were performed for $4 \mathrm{~h}$. Smears of drug-treated $E$. coli cells were made on clean slides and heat-fixed. The cells were gram stained by a gram staining kit (HiMedia, catalog no. K001), according the manufacturer's protocol. Images were taken in Leica SP8 microscope using a trans photomultiplier tube (PMT) sensor with a $63 \times$ oil immersion objective.

\section{Determination of the Cellular Ruthenium Concentration}

The HepG2 cells $\left(5 \times 10^{5}\right)$ were seeded in a $60 \mathrm{~mm}$ Petri dish at $37^{\circ} \mathrm{C}$. After $48 \mathrm{~h}$ of incubation, the medium was replenished by a fresh medium containing $5 \mu \mathrm{M}$ respective complex and incubated for $4 \mathrm{~h}$. Subsequently, the complex containing medium was removed and a fresh medium added. The cells were harvested immediately after complex removal ( 0 h) for one set and after $24 \mathrm{~h}$ of incubation with a fresh medium for another set using trypsinization. A total of $1 \times 10^{6}$ cells were taken and washed several times with $1 \times$ PBS. Finally, the cell pellets were dissolved in $100 \mu \mathrm{L}$ of ICP-MS-grade $\mathrm{HNO}_{3}$ and digested at 60 ${ }^{\circ} \mathrm{C}$ for $12 \mathrm{~h}$. The $\mathrm{HNO}_{3}$ solution was further diluted to $5 \mathrm{~mL}$ using Milli-Q water so that the final solution had $2 \% \mathrm{HNO}_{3}$. This solution was used to determine the cellular ruthenium concentrations using a Thermo Scientific iCAP RQ inductively coupled plasma mass spectrometer. For each complex, a total of six replicates were used to calculate the average intracellular ruthenium concentration. Ruthenium standard solutions used for the calibration curve were freshly prepared from a $1000 \mathrm{mg} \mathrm{L}^{-1}$ standard ruthenium solution obtained from Sigma-Aldrich.

\section{Results and Discussion}

\section{Synthesis and Characterization}

The ligands and complexes $\mathbf{1}, \mathbf{4}$, and $\mathbf{7}$ were synthesized using our reported procedures. $53,54,61$ The new complexes $(\mathbf{2}, \mathbf{3}, \mathbf{5}$, and $\mathbf{6})$ were synthesized using procedures similar to those reported earlier. $\mathrm{Ru}^{\mathrm{II}}-\eta^{6}-p$-cym complexes have been synthesized as per our previously described procedures. The bromido and iodido precursors of $\mathrm{Ru}^{\mathrm{II}}-\eta^{6}-p$-cym have been used to synthesize bromide- and iodide-coordinated complexes, respectively. The complexes were characterized by several analytical techniques including ${ }^{1} \mathrm{H}$ and ${ }^{13} \mathrm{C}$ NMR, electrospray ionization highresolution mass spectrometry (ESI-HRMS), FT-IR, and UV- vis spectral studies. The corresponding imine stretching frequencies for complexes $\mathbf{2}, \mathbf{3}, \mathbf{5}$, and $\mathbf{6}$ appear within $1625-1640 \mathrm{~cm}^{-1}$. The UV-vis spectra display ligand-to-metal charge transfer for the complexes of ca. $370-375 \mathrm{~cm}^{-1}$. HRMS and elemental analysis confirmed the bulk purity of the complexes. 


\section{X-ray Diffraction}

Suitable quality crystals for single-crystal X-ray crystallography were obtained by layering a solution of the respective complex in dichloromethane with hexane (for $\mathbf{2}, \mathbf{5}$, and $\mathbf{6}$ ) at $4{ }^{\circ} \mathrm{C}$. Complexes $\mathbf{2}$ and $\mathbf{5}$ crystallized in a monoclinic system with space group $P 2_{1} / n$, whereas $\mathbf{6}$ crystallized in $P 2_{1} / c$ (Table $\mathrm{S} 1$ ). The structures of $\mathbf{2}$ and $\mathbf{5}$ displayed the $\mathrm{Ru}-\mathrm{Br}$ bond distances as 2.529(5) and 2.534(3) $\AA$, respectively (Table S2). The Ru-N1 (imidazole ring nitrogen) bond length is less (2.073-2.085 $\AA$ ) than the Ru-N3 (Schiff base nitrogen; 2.107-2.134 $\AA$ ) in all three complexes. The N1-Ru1-N3 angle is ca. $76^{\circ}$ (Table S3), which indicated a distorted tetrahedral structure (Figure 2). Each unit cell of $\mathbf{2}$ and $\mathbf{5}$ consists of four molecules. In complex $\mathbf{2}$, the Ru-C11 (2.204 $\AA$ ) bond appears to be shorter than $\mathrm{Ru}$ -C14 (2.245 $\AA$ ), although C11 is attached to the bulkier isopropyl group and C14 to the methyl group. Complex 2 displayed hydrogen bonding (ca. $2.8 \AA$ ) between the -NH of imidazole and oxygen of a water molecule present in the unit cell with a $\angle \mathrm{N}-\mathrm{H} \cdots \mathrm{O}$ angle of ca. $161^{\circ}$ (Figure S9A). In complex 6, the asymmetric unit has three complexes (Figure S9B) because of the difference in the orientation of the individual molecules and the $\mathrm{PF}_{6}$ counteranion, thus leading to 12 molecules per unit cell. The $\mathrm{Ru}-\mathrm{I}$ bond length of $2.726 \AA$ in 6 is well comparable with the range of 2.70-2.74 $\AA$ found in the literature. ${ }^{55,56,71-73}$ Ruthenium(II) is in a distorted tetrahedral environment (Figure 2). The $\angle \mathrm{N} 1-\mathrm{Ru} 1-\mathrm{I} 1$ of ca. $81^{\circ}$ and $\angle \mathrm{N} 1-\mathrm{Ru} 1-\mathrm{N} 3$ of ca. $76^{\circ}$ in 6 are similar to those of the corresponding bromido complex 5 (Table S3).

\section{Solution Stability and Halide Exchange}

The crystal structures suggested that the metal center is in a distorted tetrahedral geometry. It was already shown that $\mathbf{4}$ and $\mathbf{7}$ were highly stable in aqueous solutions and the Ru-I bearing 7 was resistant to halide exchange. ${ }^{53,61}$ The higher stability of a complex is advantageous to lower side effects. Concentrations similar to the $\mathrm{IC}_{50}$ (or lower) of the complexes were incubated with $80 \%$ aqueous $\mathrm{NaCl}(110 \mathrm{mM})$-phosphate buffer ( $\mathrm{pH} 7.4)$, and the speciation with time was investigated by ESI-MS. The results showed that the complexes in which ruthenium(II) was bound to a bromide ( 2 and $\mathbf{5}$ ) exchanged their bonded halide with chloride within 4 and $0.5 \mathrm{~h}$, respectively (Figures S10-S12 and S16). The ruthnium iodido complexes showed resistance to exchange of halide except for the highly sterically hindered 6. The sterically hindered Schiff base ligand of 2,6-diisopropylaniline crowded the coordination sphere when the halides were bromido (5) or iodido (6); thus, this led to quick exchange of the halides to generate ruthenium chlorido complexes in solution (Figures S16-S18). In the case of the least sterically hindered ligand (L1), the iodido complex 3 was quite stable and resistant to halide exchange. Even after $24 \mathrm{~h}$, a significant amount of intact complex was observed in the presence of $110 \mathrm{mM}$ chloride at $\mathrm{pH} 7.4$ (Figures S13-S15). The ESI-MS results suggest that, with an increase in the steric bulk in the Schiff base in the vicinity of the ruthnium(II) center, coordination with the relatively small-size chloride was more favored. This was also supported by the relatively longer exchange time for the least sterically hindered complexes $\mathbf{2}$ and $\mathbf{3}$. Around $85 \%$ and $15 \%$ of the bromido and iodido were exchanged, respectively, with the chlorido in solution after $4 \mathrm{~h}$ of incubation, suggesting that the bigger halides are stable around ruthnium(II) $\eta^{6}$ - $p$-cymene if the steric crowding is less. After $24 \mathrm{~h}$, almost full exchange was observed for $\mathbf{2}$ and ca. 
$50 \%$ exchange was observed for the corresponding iodido complex (3) in $110 \mathrm{mM} \mathrm{NaCl}$

(Figures S12 and S15).

\section{GSH Binding}

Complexes 3 and $\mathbf{7}$ displayed relatively higher kinetic inertness because of their resistance to hydrolysis and halide exchange. The reactivity with GSH was already investigated for $\mathbf{7 , 4}$, and $\mathbf{1}^{53,54,61}$ but not for $\mathbf{3}$. Complex 7 exhibited only a small amount of GSH binding in the presence of excess GSH in ESI-MS, and in ${ }^{1} \mathrm{H}$ NMR, with 2 equiv of GSH no binding to the thiol was observed.

Complex 3 in the presence of $25 \mathrm{~mol}$ equiv of GSH in 2:8 (v/v) methanol-5 mM phosphate buffer (pH 7.4) and $4 \mathrm{mM} \mathrm{NaCl}$, incubated at $25^{\circ} \mathrm{C}$, was investigated for $\mathrm{GSH}$ binding. After $24 \mathrm{~h}$ of incubation, the ESI-MS results showed only a small amount of GSH adduct for 3 with the formulation $\left[(\mathrm{L} 1) \mathrm{Ru}^{\mathrm{II}}(p \text {-cym })(\mathrm{GS})\right]^{+}$along with the intact complex $\left[(\mathrm{L} 1) \mathrm{Ru}^{\mathrm{II}}(p-\right.$ cym)I $]^{+}$(Figure S20). The presence of $\mathrm{m} / z 533.996$ (calcd $\mathrm{m} / z$ 533.998) corresponding to $\left[(\mathrm{L} 1) \mathrm{Ru}^{\mathrm{II}}(p \text {-cym })\right]^{+}$suggests that $\mathbf{3}$ did not exchange halide or hydrolyze further, supporting its kinetically inert nature.

In the thiol-binding studies, we made an interesting observation that the bromido-ligated complexes were more prone to formation of GSH adduct and degradation. Complex 2 with the least sterically hindered ligand showed a GSH adduct, $\left[(\mathrm{L} 1) \mathrm{Ru}^{\mathrm{II}}(p \text {-cym })(\mathrm{GS})\right]^{+}$, after 24 h (Figure S19). Complex 5 degraded within an hour in the presence of GSH.

Since, the formula of the GSH adduct species is the same for 1-3 or 4-6 (Figure 3), the difference in ionization cannot be held responsible for this population difference, under the same ionization conditions. Hence, it is concluded that GSH adduct formation is less in $\mathbf{3}$ because of higher inertness of $\mathbf{3}$. Our earlier studies with 7, bearing the $\mathrm{Ru}-\mathrm{I}$ bond and an anthraquinone-based ligand, also displayed similar resistivity against GSH coordination. ${ }^{61}$ Thus, the iodido-bound $\mathbf{3}$ and $\mathbf{7}$ showed the highest resistivity toward thiol-based sequestration, followed by $\mathbf{4}$ (Figure 3). This makes $\mathbf{3}$ and $\mathbf{7}$ potential candidates to escape copper homeostasis pathway-mediated sequestration in the cell.

\section{Cytotoxicity}

In vitro cytotoxicity studies showed that the advantage of kinetic inertness may not always be reflected in the in vitro cytotoxicity data. Although the bromido complexes exchanged quickly with the excess chloride in solution, the dose responses for the bromido complexes were different. The cytotoxicity studies were carried out against liver carcinoma (HepG2), pancreatic adenocarcinoma (MiaPaCa-2), and triple-negative breast carcinoma (MDAMB-231) (Table 1).

Bromido-coordinated complexes $\mathbf{2}$ and $\mathbf{5}$ are cytotoxic, but they are the least stable and dissociate in the presence of excess GSH. We already knew from our earlier work that the cytotoxicity of $\mathbf{7}$ is high ${ }^{61}$ and complex $\mathbf{7}$ displays high resistivity to GSH. Complexes $\mathbf{1}$ and $\mathbf{5}$, the least sterically hindered chlorido and the most sterically hindered iodido complex (Figure 1), are next in toxicity after $\mathbf{7}$ (Table 1). However, complexes $\mathbf{1}$ and $\mathbf{5}$ are not stable in the presence of GSH and dissociate within the $24 \mathrm{~h}$ period (Figure 3). Complexes 1, 4, 
and $7^{61}$ displayed high stability along with a good cytotoxicity profile with more activity toward the liver cancer cells (Table 1). Complexes $\mathbf{1}$ and $\mathbf{4}$ are susceptible to sequestration by GSH, complex $\mathbf{3}$ appeared to be less toxic to the liver carcinoma but showed relatively better dose response in pancreatic carcinoma and triple-negative breast carcinoma. The results of cytotoxicity showed that the complexes are all active against the various cancers investigated, but their activity does not necessarily reflect their kinetic inertness or higher stability.

Complexes $\mathbf{4}$ and $\mathbf{7}$ killed cells by the apoptotic pathway and depolarized the mitochondria. Complex 3 also killed through apoptosis, as detected by Annexin V-PE/7-AAD assay using the $\mathrm{IC}_{50}$ concentration $(7.5 \mu \mathrm{M})$ against the TNBC MDA-MB-231 (Figure 4). A concentration-dependent mitochondrial membrane depolarization was observed upon treatment with $\mathbf{3}$ (in MDA-MB-231 cells; Figure S22), which indicates that $\mathbf{3}$ follows a mitochondria-mediated apoptosis pathway for cell killing.

Complexes $\mathbf{4}$ and $\mathbf{7}$ killed cells by the apoptotic pathway and depolarized the mitochondria. Complex 3 also killed through apoptosis, as detected by Annexin V-PE/7-AAD assay using the $\mathrm{IC}_{50}$ concentration $(7.5 \mu \mathrm{M})$ against the TNBC MDA-MB-231 (Figure 4). A concentration-dependent mitochondrial membrane depolarization was observed upon treatment with 3 (in MDA-MB-231 cells; Figure S22), which indicates that 3 follows a mitochondria-mediated apoptosis pathway for cell killing.

The cytotoxic efficiency in vitro does not correlate with the stability, GSH reactivity, or ATP7B sequestration of the complexes (described later). This is not unexpected, and hence the cytotoxicity alone should not be a standard for categorizing an anticancer agent. The example of oxaliplatin and carboplatin with regard to cisplatin is applicable here. Cisplatin is also found to be more toxic than carboplatin or oxaliplatin in cancer cell toxicity assay. ${ }^{74}$ However, oxaliplatin or carboplatin is more resistant to $\mathrm{Cu}$-ATPase trafficking than cisplatin. 32

\section{ATP7B Response}

Alteration of ATP7B mRNA Expression-It has been reported that cisplatin treatment in cells upregulates expression of Cu-ATPases, ${ }^{75}$ resulting in chemo-resistance. To determine whether ruthenium(II) complexes may cause transcription upregulation of $\mathrm{Cu}$ ATPases, cells were treated with 4 for $24 \mathrm{~h}$ at a dosage of $\mathrm{IC}_{20}$. Subsequently, cells were incubated in a fresh drug-free medium for $12 \mathrm{~h}$. Finally, cells were again incubated in a ruthenium-containing medium for $24 \mathrm{~h}$ at a dosage of $\mathrm{IC}_{20}$. The levels of ATP7B transcript were measured at these three time points. The three time points were considered to include the possibility of fast and slow response on the transcription regulation. In correlation with the literature, cisplatin triggered 2.5- and 1.5-fold upregulation of the ATP7B transcript at 36 and $60 \mathrm{~h}$ posttreatment, respectively (Figure 5). Interestingly, 4 bearing ruthenium(II) triggers the least change of the transcript even at $60 \mathrm{~h}$ (Figure 5). Our results suggest that unaltered levels of ATP7B mRNA in ruthenium(II)-treated cells are a potential advantage of ruthenium(II) anticancer agents over CDDP to combat drug resistance (Figure 5). The above results encourage the design and use of ruthenium(II) complexes as anticancer agents. 
Copper Cotreatment Enhanced Ru Mediated Cytotoxicity-ATP7B is a bona fide copper transporter. Hence, it may be argued that if ATP7B is responsible for ruthenium export, the copper cotreatment (simultaneous treatment) of cells will competitively inhibit ruthenium exportation by ATP7B and, hence, enhance ruthenium-mediated cytotoxicity. The expected change would only be attributed to the endogenous ATP7B in HepG2. Hence, the cytotoxicity difference would be small because of the limiting amount of ATP7B.

Cells were treated with $50 \mu \mathrm{M} \mathrm{CuCl}_{2}$, which is nontoxic for the cells under our test conditions, and $100 \%$ cell viability (Figure S23) was recorded. The treatment of copper along with $\mathbf{4}$ increased the cytotoxicity of $\mathbf{4}$ in HepG2 to $6.9 \pm 0.7 \mu \mathrm{M}$ and resulted in a higher cell mortality (Figure 6). Because the cytotoxicity is not only controlled by ATP7B sequestration even though the change is small, it does suggest the influence of ATP7B on the in vitro cytotoxicity. To ensure that this enhanced mortality induced by 4 in the presence of copper is an effect of direct copper sequestration by ATP7B and is not due to hypoxia induced by transition metals, ${ }^{76-78}$ we determined the HIF-1 $a$ levels in cells treated with the drugs in the presence and absence of copper. No alteration at the HIF-1 $a$ protein level was recorded (Figure 7). Enhancement of the toxicity of $\mathbf{4}$ may have happened because of the lowering of sequestration of $\mathbf{4}$ by ATP7B in the presence of copper.

Ruthenium Complex 4 Triggers ATP7B Trafficking-The least change in the ATP7B transcript by 4 at $60 \mathrm{~h}$, unlike CDDP, led us to examine whether ATP7B at all exports ruthenium(II) complexes from the cells, thus leading to the problem of chemoresistance similar to platinum(II) drugs. We utilized trafficking of ATP7B as a function of exportation from the cell. In the basal state, ATP7B resides at the trans-Golgi network (TGN) and transports copper to the proteins in the secretory pathway. The rise of the copper level triggers the exit of ATP7B, followed by sequestration of copper(I) in vesicles, which is subsequently exported from the cells. ${ }^{79}$.

Treatment with the sterically hindered chlorido-bound $\mathbf{4}$ showed trafficking of ATP7B from the TGN to vesicles, implying that the ruthenium(II) in these complexes are exported by the copper transporter (Figure 8). The ruthenium-(II) complex $\mathbf{4}$ has ligand L2, which shows high steric hindrance, yet the complex was extracted by ATP7B, suggesting that the ruthenium(II) center is still accessible by the binding motif CXXC. The trafficking behavior of ATP7B is similar to that of CDDP (Figure 8).

\section{Thiol Resistance: lodide-Bound 3 and 7 Do Not Elicit ATP7B Trafficking-}

Complex $\mathbf{3}$ with an iodido leaving group was more resistant to binding to the $-\mathrm{SH}$ donor in GSH than 4 (Figure S20); thus, it was expected that 3 would also be more resistant to sequestration and trafficking by ATP7B than $\mathbf{4}$. Indeed, $\mathbf{3}$ showed no vesicularization of ATP7B upon treatment, suggesting that $\mathbf{3}$ did not traffic ATP7B from the TGN, similar to the control. Interestingly, immunostaining of ATP7B in fixed HepG2 cells showed that, although vesicularization was absent in response to 3 , ATP7B exits the TGN and shows tight perinuclear accumulation, strongly suggestive of its microtubule organizing center localization (Figure 8). Thus, 3 did trigger ATP7B to exit the TGN, but for reasons not completely understood, trafficking in the vesicles was not induced. Similar to $\mathbf{3}$, iodo-ligated 7 also exhibited tight perinuclear accumulation of ATP7B. However, unlike 3, some vesicles 
of ATP7B were observed in the case of 7, but to a much lesser extent compared to 4 (Figures 8 and S24).

Resistance of the iodido-coordinated $\mathbf{3}$ and $\mathbf{7}$ toward sequestration by ATP7B shows that the iodide coligand has an important role to play in resistance to ATP7B sequestration. Ru-I coordination in $p$-cymene complexes has shown to provide mechanistic diversity. ${ }^{61}$ The results obtained by us demonstrate that with a suitable ligand the coordinated iodido may help ruthenium(II) $p$-cymene complexes escape sequestration by ATP7B.

Sequestration of Ruthenium by the N-Terminal of ATP7B-It has been demonstrated that bacteria exhibit signs of stress, viz., filament formation, when exposed to cisplatin. However, overexpression of the ATP7B N-terminal (N-ATP7B) sequestered the platinum drugs, alleviated stress, and reduced filamentation in bacteria. ${ }^{80}$ We adopted this model experiment to correlate if N-ATP7B sequesters $\mathbf{4}$ and $\mathbf{3}$. Complexes $\mathbf{3}$ and $\mathbf{4}$ induced stress to various extents in E. coli (BL21; Figure 9). When N-ATP7B was overexpressed for $4 \mathrm{~h}$ in the bacteria, there was alleviation of stress induced by 4 . No such rescue was found in bacteria overexpressing N-ATP7B treated with 3 because the filament length stays similar in both N-ATP7B $(+)$ and the control bacteria (Figure 9). Thus, it is evident that the enhanced thiol-resistant iodide-bound complex $\mathbf{3}$ escapes sequestration by N-ATP7B.

Comparison of the Ruthenium Concentrations inside Cells-Our studies for the first time show that ruthenium(II) complexes are also susceptible to sequestration by ATP7B, which would affect their dose response. Sequestration by ATP7B would allow the expulsion of ruthenium(II) from cells with an increase in time, and this would be less for the Ru-Iligated 3 and 7. In order to gain insight, the HepG2 cells were incubated for $4 \mathrm{~h}$ with either 3,4 , or 7 . The medium containing the complexes was then removed, and a fresh medium was added. We measured the total intracellular ruthenium concentration using ICP-MS at two different time points: once after immediate removal and then after $24 \mathrm{~h}$ of removal of the complexes. The ruthenium content was found to be $4>7>3$ (Figure 10), where 4 and 7 are more lipophilic than 3 . During the $24 \mathrm{~h}$ of incubation in a fresh culture medium after removal of the complexes, the efflux processes led to maximum expulsion of $\mathbf{4}$, as reflected by a ca. 2.5 times decrease in the intracellular ruthenium concentration (Figure 10) compared to the 1.9 times decrease observed for $\mathbf{3}$. It must be noted here that a decrease in the ruthenium concentration with time is expected for all of the complexes because there are multiple pathways of extraction, but the stable $\mathrm{Ru}-\mathrm{I}$ coordination did inhibit the efflux process. The plot of the ratio of the ruthenium concentration measured after immediate removal of the drug from the medium and after $24 \mathrm{~h}$ shows that $\mathbf{3}$ and $\mathbf{7}$ is retained more inside cells (Figure 10B) compared to $\mathbf{4}$. Complex 4 displays a good cytotoxicity profile and a solution half-life of more than $16 \mathrm{~h}^{53,54,61}$ in $4 \mathrm{mM} \mathrm{NaCl}$ concentration at $\mathrm{pH}$ 7.4; however, it still succumbs to ATP7B-mediated sequestration.

\section{Conclusions}

The studies presented here show that ruthenium(II) $p$-cymene half-sandwich complexes are susceptible to ATP7B-based sequestration depending on the attached ligand(s), even if they appear to be stable hydrolytically and appear to be quite cytotoxic. However, the mRNA 
profiling studies with $\mathbf{4}$ suggest that, although efficiently sequestered by ATP7B, ruthenium(II), unlike platinum(II), does not show transcription upregulation of ATP7B. This aspect of the ruthenium(II) complexes puts them in a relatively better position over the ATP7Bsequestered platinum(II) complexes. Our work demonstrates that a stable $\mathrm{Ru}-\mathrm{I}$ linkage is strong enough to resist ATP7B-based sequestration. Thus, the affinity to exchange the ligand for thiol donors can be controlled with suitable halide coordination.

\section{Supplementary Material}

Refer to Web version on PubMed Central for supplementary material.

\section{Acknowledgments}

The authors sincerely acknowledge the annual research funding and infrastructural facilities of the IISER Kolkata. K.P. thanks University Grants Commission and Ruturaj thanks IISER Kolkata for their research fellowships. The authors sincerely thank Tamal Ghosh for helping with flow cytometry analysis studies. We acknowledge Dr. Rahul Banerjee (DCS, IISER Kolkata) for his help with the X-ray structure of complex 6.

Funding

The work presented in this manuscript is extramurally funded by the Science and Engineering Research Board (SERB), Department of Science and Technology, Government of India, via Project EMR/2017/002324 to A.M. and a Wellcome Trust India Alliance Fellowship (IA///16/1/502369) and an Early Career Research Award (ECR/ 2015/000220) from the SERB, Department of Science and Technology, Government of India, to A.G.

\section{References}

(1). Noffke AL, Habtemariam A, Pizarro AM, Sadler PJ. Designing organometallic compounds for catalysis and therapy. Chem Commun. 2012; 48(43):5219-5246.

(2). Hanif M, Hartinger CG. Anticancer metallodrugs: where is the next cisplatin? Future Med Chem. 2018; 10(6):615-617. [PubMed: 29411994]

(3). Kenny RG, Marmion CJ. Toward Multi-Targeted Platinum and Ruthenium Drugs-A New Paradigm in Cancer Drug Treatment Regimens? Chem Rev. 2019; 119(2):1058-1137. [PubMed: 30640441]

(4). Murray BS, Menin L, Scopelliti R, Dyson PJ. Conformational control of anticancer activity: the application of arene-linked dinuclear ruthenium(ii) organometallics. Chem Sci. 2014; 5(6):25362545.

(5). Clavel CM, Paunescu E, Nowak-Sliwinska P, Griffioen AW, Scopelliti R, Dyson PJ. Modulating the Anticancer Activity of Ruthenium(II)-Arene Complexes. J Med Chem. 2015; 58(8):33563365. [PubMed: 25812075]

(6). Kubanik M, Kandioller W, Kim K, Anderson RF, Klapproth E, Jakupec MA, Roller A, Sohnel T, Keppler BK, Hartinger CG. Towards targeting anticancer drugs: ruthenium(II)-arene complexes with biologically active naphthoquinone-derived ligand systems. Dalton Trans. 2016; 45(33):13091-13103. [PubMed: 27214822]

(7). Meier-Menches SM, Gerner C, Berger W, Hartinger CG, Keppler BK. Structure-activity relationships for ruthenium and osmium anticancer agents - towards clinical development. Chem Soc Rev. 2018; 47(3):909-928. [PubMed: 29170783]

(8). Wang X, Wang X, Jin S, Muhammad N, Guo Z. Stimuli-Responsive Therapeutic Metallodrugs. Chem Rev. 2019; 119(2):1138-1192. [PubMed: 30299085]

(9). Lameijer LN, Hopkins SL, Breve TG, Askes SHC, Bonnet S. D-Versus L-Glucose Conjugation: Mitochondrial Targeting of a Light-Activated Dual-Mode-of-Action Ruthenium-Based Anticancer Prodrug. Chem Eur J. 2016; 22(51):18484-18491. [PubMed: 27859843] 
(10). Garci A, Dobrov AA, Riedel T, Orhan E, Dyson PJ, Arion VB, Therrien B. Strategy to Optimize the Biological Activity of Arene Ruthenium Metalla-Assemblies. Organometallics. 2014; 33(14):3813-3822.

(11). Barry NPE, Sadler PJ. Dicarba-closo-dodecarborane-containing half-sandwich complexes of ruthenium, osmium, rhodium and iridium: biological relevance and synthetic strategies. Chem Soc Rev. 2012; 41(8):3264-3279. [PubMed: 22307021]

(12). Liu Z, Sadler PJ. Organoiridium Complexes: Anticancer Agents and Catalysts. Acc Chem Res. 2014; 47(4):1174-1185. [PubMed: 24555658]

(13). Johnstone TC, Suntharalingam K, Lippard SJ. The Next Generation of Platinum Drugs: Targeted Pt(II) Agents, Nanoparticle Delivery, and Pt(IV) Prodrugs. Chem Rev. 2016; 116(5):3436-3486. [PubMed: 26865551]

(14). Pizarro AM, Sadler PJ. Cancer chemistry: designing new drugs for cancer treatment. Mol Biol Cancer. 2013:438-460.

(15). Li Y-Q, Yin J-Y, Liu Z-Q, Li X-P. Copper efflux transporters ATP7A and ATP7B: Novel biomarkers for platinum drug resistance and targets for therapy. IUBMB Life. 2018; 70(3):183191. [PubMed: 29394468]

(16). Burger H, Loos WJ, Eechoute K, Verweij J, Mathijssen RHJ, Wiemer EAC. Drug transporters of platinum-based anticancer agents and their clinical significance. Drug Resist Updates. 2011; 14(1):22-34.

(17). Katano K, Safaei R, Samimi G, Holzer A, Rochdi M, Howell SB. The copper export pump ATP7B modulates the cellular pharmacology of carboplatin in ovarian carcinoma cells. Mol Pharmacol. 2003; 64(2):466-473. [PubMed: 12869652]

(18). Leonhardt K, Gebhardt R, Moessner J, Lutsenko S, Huster D. Functional Interactions of CuATPase ATP7B with Cisplatin and the Role of ATP7B in the Resistance of Cells to the Drug. J Biol Chem. 2009; 284(12):7793-7802. [PubMed: 19141620]

(19). Komatsu M, Sumizawa T, Mutoh M, Chen Z-S, Terada K, Furukawa T, Yang X-L, Gao H, Miura N, Sugiyama T, Akiyama S-I. Copper-transporting P-type adenosine triphosphatase (ATP7B) is associated with cisplatin resistance. Cancer Res. 2000; 60(5):1312-1316. [PubMed: 10728692]

(20). Safaei R, Adams PL, Maktabi MH, Mathews RA, Howell SB. The CXXC motifs in the metal binding domains are required for ATP7B to mediate resistance to cisplatin. J Inorg Biochem. 2012; 110:8-17. [PubMed: 22459168]

(21). Mangala LS, Zuzel V, Schmandt R, Leshane ES, Halder JB, Armaiz-Pena GN, Spannuth WA, Tanaka T, Shahzad MMK, Lin YG, Nick AM, et al. Therapeutic Targeting of ATP7B in Ovarian Carcinoma. Clin Cancer Res. 2009; 15(11):3770-3780. [PubMed: 19470734]

(22). Forbes JR, Cox DW. Copper-dependent trafficking of Wilson disease mutant ATP7B proteins. Hum Mol Genet. 2000; 9(13):1927-1935. [PubMed: 10942420]

(23). Strausak D, La Fontaine S, Hill J, Firth SD, Lockhart PJ, Mercer JFB. The role of GMXCXXC metal binding sites in the copper-induced redistribution of the Menkes protein. J Biol Chem. 1999; 274(16):11170-11177. [PubMed: 10196202]

(24). Schaefer M, Hopkins RG, Failla ML, Gitlin JD. Hepatocyte-specific localization and copperdependent trafficking of the Wilson's disease protein in the liver. Am J Physiol. 1999; 276(3):G639-G646. [PubMed: 10070040]

(25). Nakayama K, Miyazaki K, Kanzaki A, Fukumoto M, Takebayashi Y. Expression and cisplatin sensitivity of copper-transporting P-type adenosine triphosphatase (ATP7B) in human solid carcinoma cell lines. Oncol Rep. 2001; 8(6):1285-1287. [PubMed: 11605050]

(26). Nakayama K, Kanzaki A, Ogawa K, Miyazaki K, Neamati N, Takebayashi Y. Coppertransporting P-type adenosine triphos-phatase (ATP7B) as a cisplatin based chemoresistance marker in ovarian carcinoma: Comparative analysis with expression of MDR1, MRP1, MRP2, LRP and BCRP. Int J Cancer. 2002; 101(5):488-495. [PubMed: 12216079]

(27). Kanzaki A, Toi M, Neamati N, Miyashita H, Oubu M, Nakayama K, Bando H, Ogawa K, Mutoh M, Mori S, Terada K, et al. Copper-transporting P-type adenosine triphosphatase (ATP7B) is expressed in human breast carcinoma. Jpn J Cancer Res. 2002; 93(1):70-77. [PubMed: 11802810] 
(28). Higashimoto M, Kanzaki A, Shimakawa T, Konno S, Naritaka Y, Nitta Y, Mori S, Shirata S, Yoshida A, Terada K, Sugiyama T, et al. Expression of copper-transporting P-type adenosine triphosphatase in human esophageal carcinoma. Int J Mol Med. 2003; 11(3):337-341. [PubMed: 12579336]

(29). Miyashita H, Nitta Y, Mori S, Kanzaki A, Nakayama K, Terada K, Sugiyama T, Kawamura H, Sato A, Morikawa H, Motegi K, et al. Expression of copper-transporting P-type adenosine triphosphatase (ATP7B) as a chemoresistance marker in human oral squamous cell carcinoma treated with cisplatin. Oral Oncol. 2003; 39(2):157-162. [PubMed: 12509969]

(30). Ohbu M, Ogawa K, Konno S, Kanzaki A, Terada K, Sugiyama T, Takebayashi Y. Coppertransporting P-type adenosine triphosphatase (ATP7B) is expressed in human gastric carcinoma. Cancer Lett. 2003; 189(1):33-38. [PubMed: 12445675]

(31). Samimi G, Varki NM, Wilczynski S, Safaei R, Alberts DS, Howell SB. Increase in expression of the copper transporter ATP7A during platinum drug-based treatment is associated with poor survival in ovarian cancer patients. Clin Cancer Res. 2003; 9(16):5853-5859. [PubMed: 14676106]

(32). Samimi G, Safaei R, Katano K, Holzer AK, Rochdi M, Tomioka M, Goodman M, Howell SB. Increased expression of the copper efflux transporter ATP7A mediates resistance to cisplatin, carboplatin, and oxaliplatin in ovarian cancer cells. Clin Cancer Res. 2004; 10(14):4661-4669. [PubMed: 15269138]

(33). Samimi G, Katano K, Holzer AK, Safaei R, Howell SB. Modulation of the cellular pharmacology of cisplatin and its analogs by the copper exporters ATP7A and ATP7B. Mol Pharmacol. 2004; 66(1):25-32. [PubMed: 15213293]

(34). Thota S, Rodrigues DA, Crans DC, Barreiro EJ. Ru(II) Compounds: Next-Generation Anticancer Metallotherapeutics? J Med Chem. 2018; 61(14):5805-5821. [PubMed: 29446940]

(35). Lenis-Rojas OA, Robalo MP, Tomaz AI, Carvalho A, Fernandes AR, Marques F, Folgueira M, Yanez J, Vazquez-Garcia D, Lopez Torres M, Fernandez A, et al. Ru(II)(p-cymene) Compounds as Effective and Selective Anticancer Candidates with No Toxicity in Vivo. Inorg Chem. 2018; 57(21):13150-13166. [PubMed: 30339386]

(36). Lenis-Rojas OA, Robalo MP, Tomaz AI, Carvalho A, Fernandes AR, Marques F, Folgueira M, Yanez J, Vazquez-Garcia D, Lopez Torres M, Fernandez A, et al. RuII(p-cymene) Compounds as Effective and Selective Anticancer Candidates with No Toxicity in Vivo. Inorg Chem. 2018; 57(21):13150-13166. [PubMed: 30339386]

(37). Li J, Tian M, Tian Z, Zhang S, Yan C, Shao C, Liu Z. Half-Sandwich Iridium(III) and Ruthenium(II) Complexes Containing P-P-Chelating Ligands: A New Class of Potent Anticancer Agents with Unusual Redox Features. Inorg Chem. 2018; 57(4):1705-1716. [PubMed: 29400963]

(38). Pettinari R, Marchetti F, Di Nicola C, Pettinari C, Galindo A, Petrelli R, Cappellacci L, Cuccioloni M, Bonfili L, Eleuteri AM, Guedes da Silva MFC, et al. Ligand Design for N,O- or N,N-Pyrazolone-Based Hydrazones Ruthenium-(II)-Arene Complexes and Investigation of Their Anticancer Activity. Inorg Chem. 2018; 57(22):14123-14133. [PubMed: 30362721]

(39). Zhao J, Li W, Gou S, Li S, Lin S, Wei Q, Xu G. Hypoxia-Targeting Organometallic Ru(II)-Arene Complexes with Enhanced Anticancer Activity in Hypoxic Cancer Cells. Inorg Chem. 2018; 57(14):8396-8403. [PubMed: 29953210]

(40). Mohamed Kasim MS, Sundar S, Rengan R. Synthesis and structure of new binuclear ruthenium(II) arene benzil bis-(benzoylhydrazone) complexes: investigation on antiproliferative activity and apoptosis induction. Inorg Chem Front. 2018; 5(3):585-596.

(41). Du Q, Guo L, Tian M, Ge X, Yang Y, Jian X, Xu Z, Tian Z, Liu Z. Potent Half-Sandwich Iridium(III) and Ruthenium-(II) Anticancer Complexes Containing a $\mathrm{P}^{\wedge} \mathrm{O}-$ Chelated Ligand. Organometallics. 2018; 37(17):2880-2889.

(42). Gatti A, Habtemariam A, Romero-Canelon I, Song J-I, Heer B, Clarkson GJ, Rogolino D, Sadler PJ, Carcelli M. Half-Sandwich Arene Ruthenium(II) and Osmium(II) Thiosemicarbazone Complexes: Solution Behavior and Antiproliferative Activity. Organometallics. 2018; 37(6):891899. [PubMed: 29681675] 
(43). Aird RE, Cummings J, Ritchie AA, Muir M, Morris RE, Chen H, Sadler PJ, Jodrell DI. In vitro and in vivo activity and cross resistance profiles of novel ruthenium (II) organometallic arene complexes in human ovarian cancer. Br J Cancer. 2002; 86(10):1652-1657. [PubMed: 12085218]

(44). Habtemariam A, Melchart M, Fernandez R, Parsons S, Oswald IDH, Parkin A, Fabbiani FPA, Davidson JE, Dawson A, Aird RE, Jodrell DI, et al. Structure-Activity Relationships for Cytotoxic Ruthenium(II) Arene Complexes Containing N,N-, N,O-, and O, O-Chelating Ligands. J Med Chem. 2006; 49(23):6858-6868. [PubMed: 17154516]

(45). van Rijt SH, Hebden AJ, Amaresekera T, Deeth RJ, Clarkson GJ, Parsons S, McGowan PC, Sadler PJ. Amide linkage isomerism as an activity switch for organometallic osmium and ruthenium anticancer complexes. J Med Chem. 2009; 52(23):7753-7764. [PubMed: 19791745]

(46). Grozav A, Balacescu O, Balacescu L, Cheminel T, Berindan-Neagoe I, Therrien B. Synthesis, Anticancer Activity, and Genome Profiling of Thiazolo Arene Ruthenium Complexes. J Med Chem. 2015; 58(21):8475-8490. [PubMed: 26488797]

(47). Lord RM, Hebden AJ, Pask CM, Henderson IR, Allison SJ, Shepherd SL, Phillips RM, McGowan PC. Hypoxia-Sensitive Metal $\beta$-Ketoiminato Complexes Showing Induced SingleStrand DNA Breaks and Cancer Cell Death by Apoptosis. J Med Chem. 2015; 58(12):49404953. [PubMed: 25906293]

(48). Yellol J, Perez SA, Buceta A, Yellol G, Donaire A, Szumlas P, Bednarski PJ, Makhloufi G, Janiak C, Espinosa A, Ruiz J. Novel C,N-Cyclometalated Benzimidazole Ruthenium(II) and Iridium(III) Complexes as Antitumor and Antiangiogenic Agents: A Structure-Activity Relationship Study. J Med Chem. 2015; 58(18):7310-7327. [PubMed: 26313136]

(49). Chow MJ, Licona C, Pastorin G, Mellitzer G, Ang WH, Gaiddon C. Structural tuning of organoruthenium compounds allows oxidative switch to control ER stress pathways and bypass multidrug resistance. Chem Sci. 2016; 7(7):4117-4124. [PubMed: 30155055]

(50). Weiss A, Berndsen RH, Dubois M, Muller C, Schibli R, Griffioen AW, Dyson PJ, NowakSliwinska P. In vivo anti-tumor activity of the organometallic ruthenium(II)-arene complex $[\mathrm{Ru}(\eta 6$-p-cymene)Cl2(pta)] (RAPTA-C) in human ovarian and colorectal carcinomas. Chem Sci. 2014; 5(12):4742-4748.

(51). Gupta A, Das S, Ray K. A glimpse into the regulation of the Wilson disease protein, ATP7B, sheds light on the complexity of mammalian apical trafficking pathways. Metallomics. 2018; 10(3):378-387. [PubMed: 29473088]

(52). Nakayama K, Kanzaki A, Terada K, Mutoh M, Ogawa K, Sugiyama T, Takenoshita S, Itoh K, Yaegashi N, Miyazaki K, Neamati N, et al. Prognostic value of the Cu-transporting ATPase in ovarian carcinoma patients receiving cisplatin-based chemotherapy. Clin Cancer Res. 2004; 10(8):2804-2811. [PubMed: 15102688]

(53). Purkait K, Karmakar S, Bhattacharyya S, Chatterjee S, Dey SK, Mukherjee A. A hypoxia efficient imidazole-based RuII arene anticancer agent resistant to deactivation by glutathione. Dalton Trans. 2015; 44(13):5969-5973. [PubMed: 25742181]

(54). Purkait K, Chatterjee S, Karmakar S, Mukherjee A. Alteration of steric hindrance modulates glutathione resistance and cytotoxicity of three structurally related RuII-p-cymene complexes. Dalton Trans. 2016; 45(20):8541-8555. [PubMed: 27120485]

(55). Moon S, Hanif M, Kubanik M, Holtkamp H, Soehnel T, Jamieson SMF, Hartinger CG. Organoruthenium and Osmium Anticancer Complexes Bearing a Maleimide Functional Group: Reactivity to Cysteine, Stability, and Cytotoxicity. ChemPlusChem. 2015; 80(1):231-236.

(56). Betanzos-Lara S, Novakova O, Deeth RJ, Pizarro AM, Clarkson GJ, Liskova B, Brabec V, Sadler PJ, Habtemariam A. Bipyrimidine ruthenium(II) arene complexes: structure, reactivity and cytotoxicity. JBIC J Biol Inorg Chem. 2012; 17:1033-1051. [PubMed: 22791215]

(57). Bugarcic T, Habtemariam A, Deeth RJ, Fabbiani FPA, Parsons S, Sadler PJ. Ruthenium(II) Arene Anticancer Complexes with Redox-Active Diamine Ligands. Inorg Chem. 2009; 48(19):94449453. [PubMed: 19780621]

(58). Dougan SJ, Habtemariam A, McHale SE, Parsons S, Sadler PJ. Catalytic organometallic anticancer complexes. Proc Natl Acad Sci U S A. 2008; 105(33):11628-11633. [PubMed: 18687892] 
(59). Romero-Canelon I, Salassa L, Sadler PJ. The Contrasting Activity of Iodido versus Chlorido Ruthenium and Osmium Arene Azo- and Imino-pyridine Anticancer Complexes: Control of Cell Selectivity, Cross-Resistance, p53 Dependence, and Apoptosis Pathway. J Med Chem. 2013; 56(3):1291-1300. [PubMed: 23368735]

(60). Romero-Canelon I, Pizarro AM, Habtemariam A, Sadler PJ. Contrasting cellular uptake pathways for chlorido and iodido iminopyridine ruthenium arene anticancer complexes. Metallomics. 2012; 4(12):1271-1279. [PubMed: 23138378]

(61). Sarkar A, Acharya S, Khushvant K, Purkait K, Mukherjee A. Cytotoxic RuII-p-cymene complexes of an anthraimidazoledione: halide dependent solution stability, reactivity and resistance to hypoxia deactivation. Dalton Trans. 2019; 48:7187-7197. [PubMed: 30601545]

(62). Perrin, DD, Armarego, WLF. Purification of Laboratory Chemicals. 3rd ed. Pergamon Press; Oxford, U.K.: 1988. 391

(63). Bennett MA, Huang TN, Matheson TW, Smith AK, Ittel S, Nickerson W. ( $\eta 6-$ Hexamethylbenzene)ruthenium complexes. Inorg Synth. 2007; 21:74-78.

(64). Palatinus L, Chapuis G. SUPERFLIP. A computer program for the solution of crystal structures by charge flipping in arbitrary dimensions. J Appl Crystallogr. 2007; 40(4):786-790.

(65). Sheldrick GM. A short history of SHELX. Acta Crystallogr Sect: A Found Crystallogr. 2008; 64:112-122.

(66). Dolomanov OV, Bourhis LJ, Gildea RJ, Howard JAK, Puschmann H. OLEX2: a complete structure solution, refinement and analysis program. J Appl Crystallogr. 2009; 42(2):339-341.

(67). Sheldrick GM. Tutorial on automated Patterson interpretation to find heavy atoms. Int Union Crystallogr, Crystallogr Symp. 1991; 5:145-157.

(68). Lokeshwar BL, Escatel E, Zhu B. Cytotoxic activity and inhibition of tumor cell invasion by derivatives of a chemically modified tetracycline CMT-3 (COL-3). Curr Med Chem. 2001; 8(3):271-279. [PubMed: 11172682]

(69). Alley MC, Scudiero DA, Monks A, Hursey ML, Czerwinski MJ, Fine DL, Abbott BJ, Mayo JG, Shoemaker RH, Boyd MR. Feasibility of drug screening with panels of human tumor cell lines using a microculture tetrazolium assay. Cancer Res. 1988; 48(3):589-601. [PubMed: 3335022]

(70). Braiterman L, Nyasae L, Guo Y, Bustos R, Lutsenko S, Hubbard A. Apical targeting and Golgi retention signals reside within a 9-amino acid sequence in the copper-ATPase, ATP7B. Am J Physiol. 2009; 296(2):G433-G444.

(71). Ashraf A, Hanif M, Kubanik M, Sohnel T, Jamieson SMF, Bhattacharyya A, Hartinger CG. Aspirin-inspired organometallic compounds: Structural characterization and cytotoxicity. J Organomet Chem. 2017; 839:31-37.

(72). Pantic DN, Arandelovic S, Radulovic S, Roller A, Arion VB, Grguric-Sipka S. Synthesis, characterisation and cytotoxic activity of organoruthenium(II)-halido complexes with $1 \mathrm{H}-$ benzimi-dazole-2-carboxylic acid. J Organomet Chem. 2016; 819:61-68.

(73). Berger I, Hanif M, Nazarov AA, Hartinger CG, John RO, Kuznetsov ML, Groessl M, Schmitt F, Zava O, Biba F, Arion VB, et al. In vitro anticancer activity and biologically relevant metabolization of organometallic ruthenium complexes with carbohydrate-based ligands. Chem Eur J. 2008; 14(29):9046-9057. [PubMed: 18688905]

(74). Koch S, Mayer F, Honecker F, Schittenhelm M, Bokemeyer C. Efficacy of cytotoxic agents used in the treatment of testicular germ cell tumours under normoxic and hypoxic conditions in vitro. Br J Cancer. 2003; 89(11):2133-2139. [PubMed: 14647149]

(75). Katano K, Kondo A, Safaei R, Holzer A, Samimi G, Mishima M, Kuo Y-M, Rochdi M, Howell $\mathrm{SB}$. Acquisition of resistance to cisplatin is accompanied by changes in the cellular pharmacology of copper. Cancer Res. 2002; 62(22):6559-6565. [PubMed: 12438251]

(76). Chandel NS, Maltepe E, Goldwasser E, Mathieu CE, Simon MC, Schumacker PT. Mitochondrial reactive oxygen species trigger hypoxia-induced transcription. Proc Natl Acad Sci U S A. 1998; 95(20):11715-11720. [PubMed: 9751731]

(77). Wang GL, Semenza GL. Characterization of hypoxia-inducible factor 1 and regulation of DNA binding activity by hypoxia. J Biol Chem. 1993; 268(29):21513-21518. [PubMed: 8408001] 
(78). Wang GL, Semenza GL. Desferrioxamine induces erythropoietin gene expression and hypoxiainducible factor 1 DNA-binding activity: implications for models of hypoxia signal transduction. Blood. 1993; 82(12):3610-3615. [PubMed: 8260699]

(79). Polishchuk EV, Concilli M, Iacobacci S, Chesi G, Pastore N, Piccolo P, Paladino S, Baldantoni D, van Ijzendoorn SCD, Chan J, Chang CJ, et al. Wilson Disease Protein ATP7B Utilizes Lysosomal Exocytosis to Maintain Copper Homeostasis. Dev Cell. 2014; 29(6):686-700. [PubMed: 24909901]

(80). Dolgova NV, Olson D, Lutsenko S, Dmitriev OY. The soluble metal-binding domain of the copper transporter ATP7B binds and detoxifies cisplatin. Biochem J. 2009; 419(1):51-56. [PubMed: 19173677] 


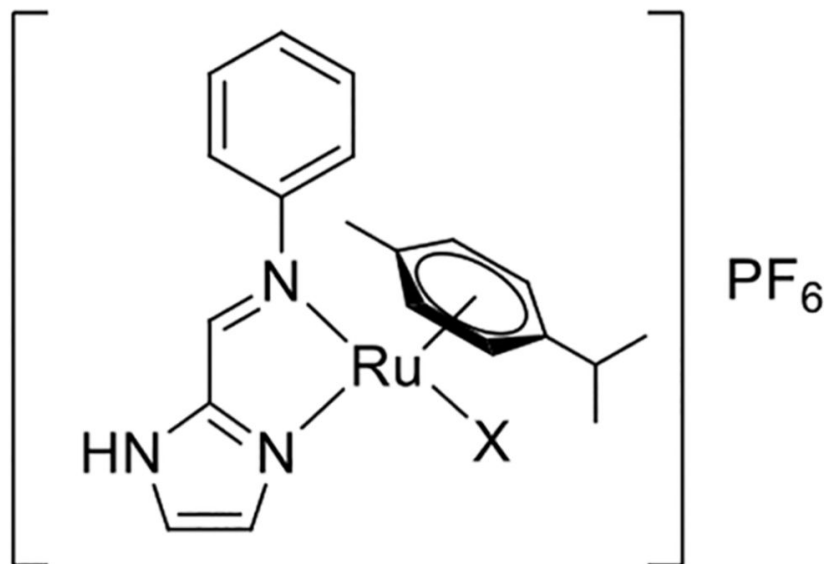

$\mathrm{X}=\mathrm{Cl}(\mathbf{1}), \mathrm{Br}(2), \mathrm{I}(3)$
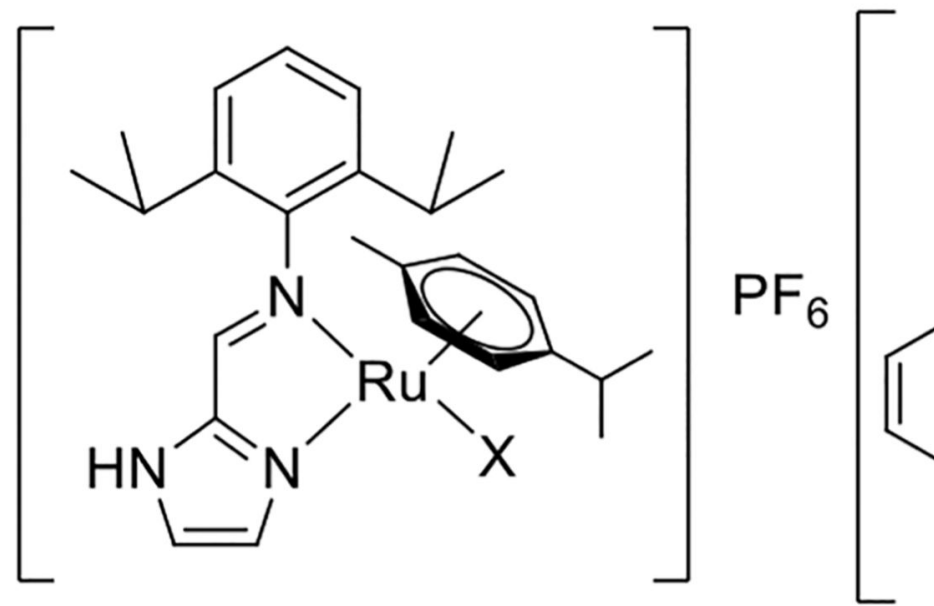

$X=C l(4), \operatorname{Br}(5), I(6)$

7

Figure 1.

Chemical structures of complexes 1-7. 


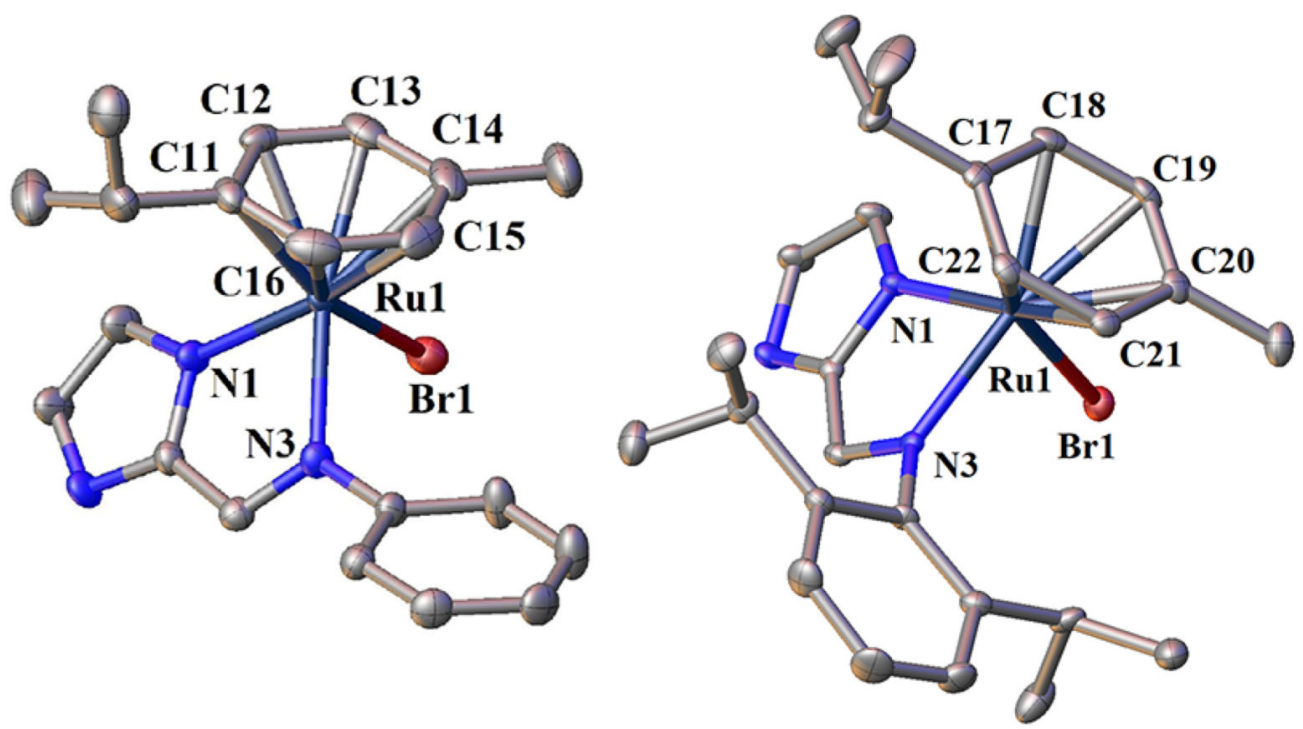

2

5

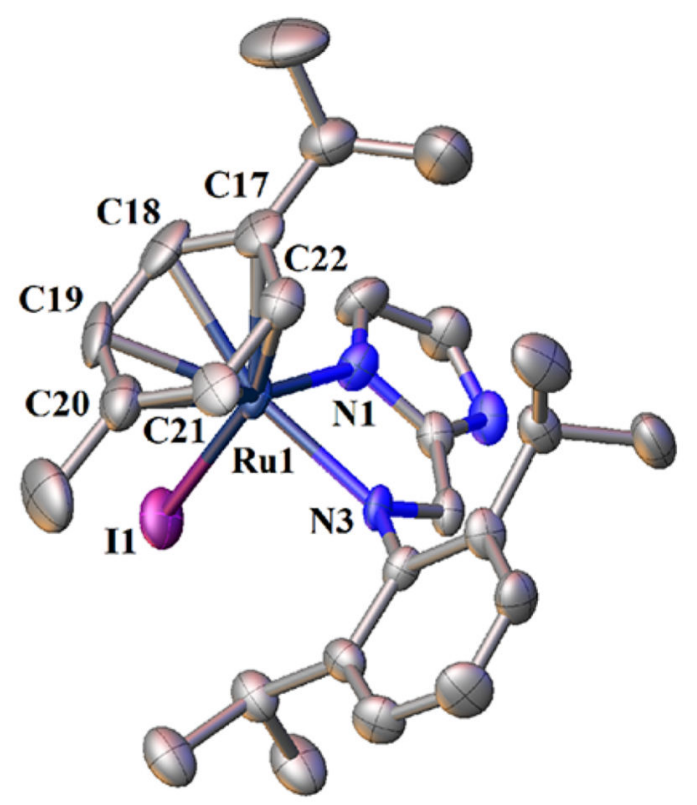

6

Figure 2.

Molecular structures of complexes 2, 5, and $\mathbf{6}$ with 50\% probability level thermal ellipsoids obtained from SCXRD. In $\mathbf{6}$, only one molecule from the asymmetric unit is displayed for clarity. Solvent molecules, hydrogen atoms, and counteranions are omitted for clarity. 


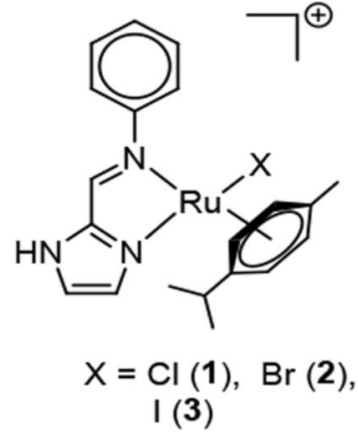<smiles>NC(CCC(=O)NC(CS)C(=O)NCC(=O)O)C(=O)O</smiles>

Glutathione (GSH)<smiles>CC(C)CCCCC(C)C(C)C</smiles>

Major for 2<smiles></smiles>

Major for 3

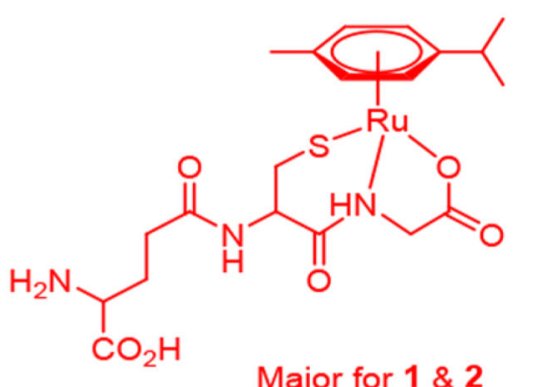

Degradation after $24 \mathrm{~h}$ for complexes 2

$5 \mathrm{mM}$ phosphate buffer $(\mathrm{pH} 7.4)$

$4 \mathrm{mM}$ saline: methanol 8:2 ( $\mathrm{v} / \mathrm{v})$

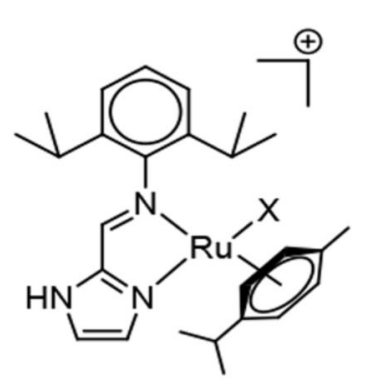

$X=\mathrm{Cl}(\mathbf{4}), \mathrm{Br}(5)$,

I (6)

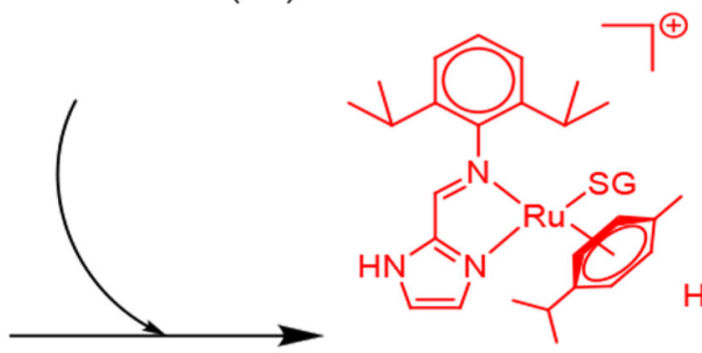

Major for 4<smiles>Cc1ccc(C(C)C)c(SCC(NC(=O)CCC(N)C(=O)O)C(=O)N2CCOC(=O)C2)c1</smiles>

Major for $\mathbf{4}$

Degradation after $24 \mathrm{~h}$

for complexes 5 \& 6

Figure 3.

Speciation and stability of the complexes in the presence of 25 equiv of GSH at pH 7.4 in the presence of $4 \mathrm{mM} \mathrm{NaCl}$. 

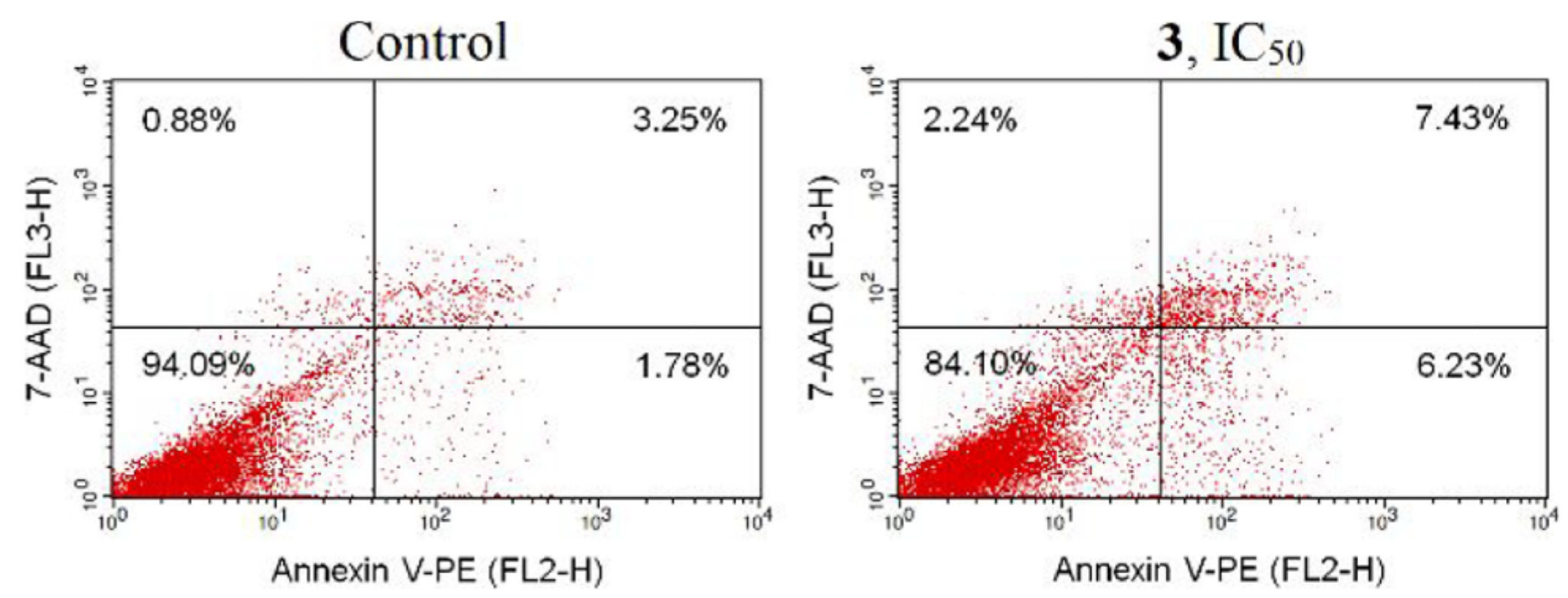

Figure 4.

Apoptosis induction of MDA-MB-231 cells by complex $\mathbf{3}$. The four quadrants are as follows: lower left, viable cells; lower right, early apoptosis; upper right, late apoptosis; upper left, necrosis. 


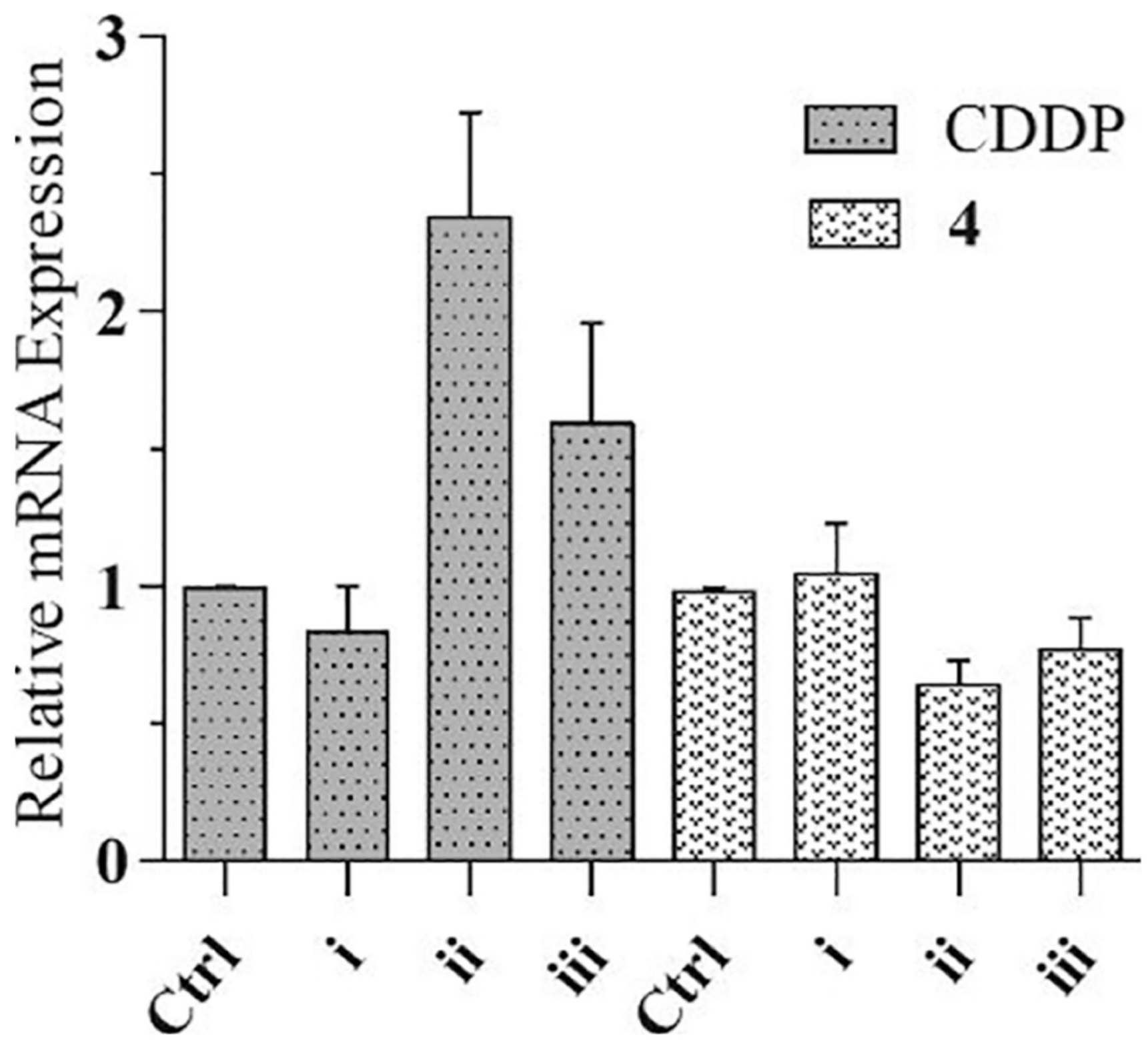

Figure 5.

Levels of ATP7B mRNA in HepG2 in response to CDDP and ruthenium complex 4. Cells were treated with complexes for $24 \mathrm{~h}$ (i). Subsequently, cells were incubated in a fresh complex-free medium for $12 \mathrm{~h}$ (ii). Finally, cells were again incubated in a ruthniumcontaining medium for $24 \mathrm{~h}$ (iii). 


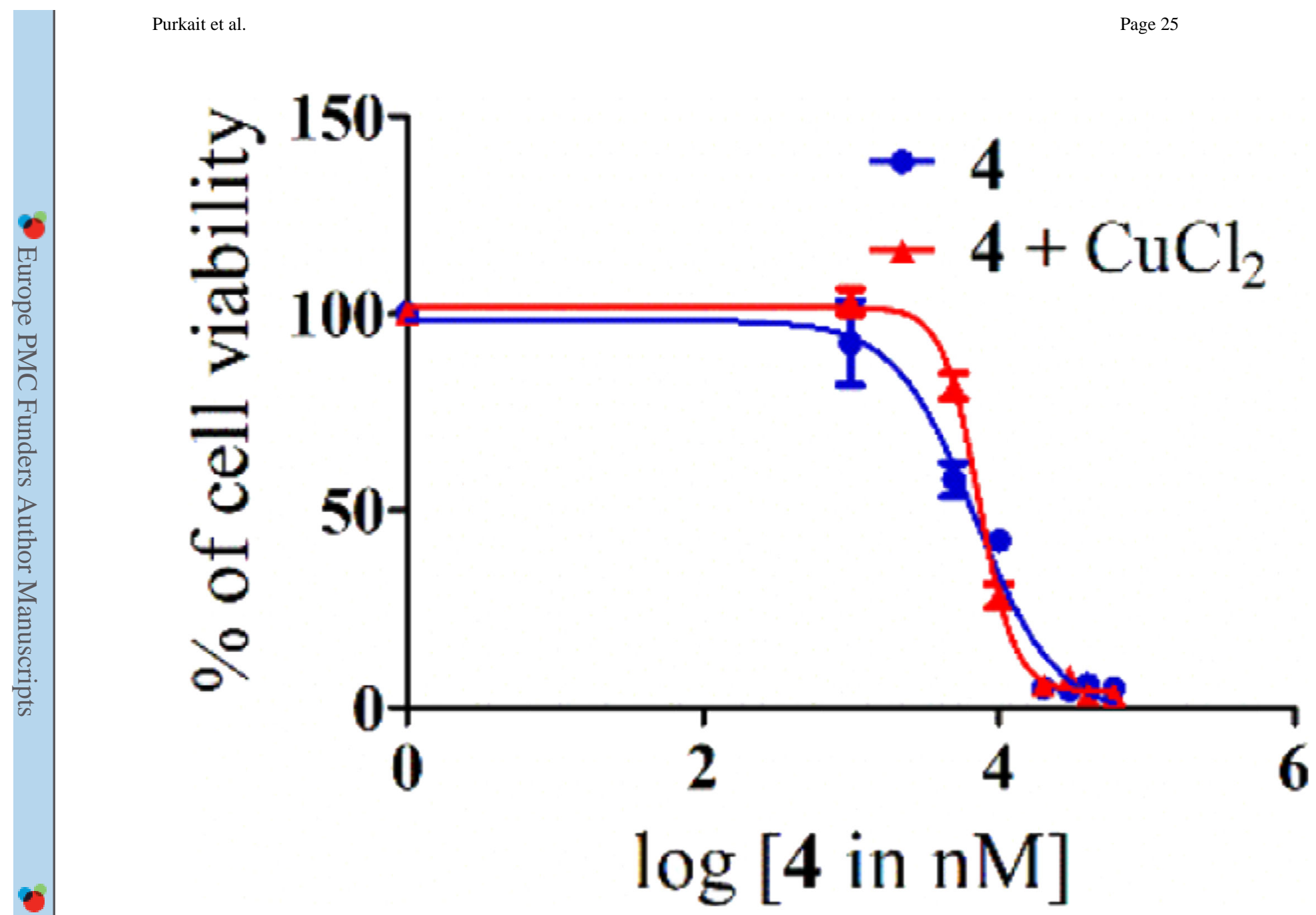

Figure 6.

Viability (\%) of HepG2 cells determined by NR assay after 48 h of treatment with 4 in the presence of $50 \mu \mathrm{M} \mathrm{CuCl}_{2}$ in normoxic condition in comparison to treatment with only 4 .

The plots provided are for one independent experiment out of the three independent experiments performed with each concentration. 


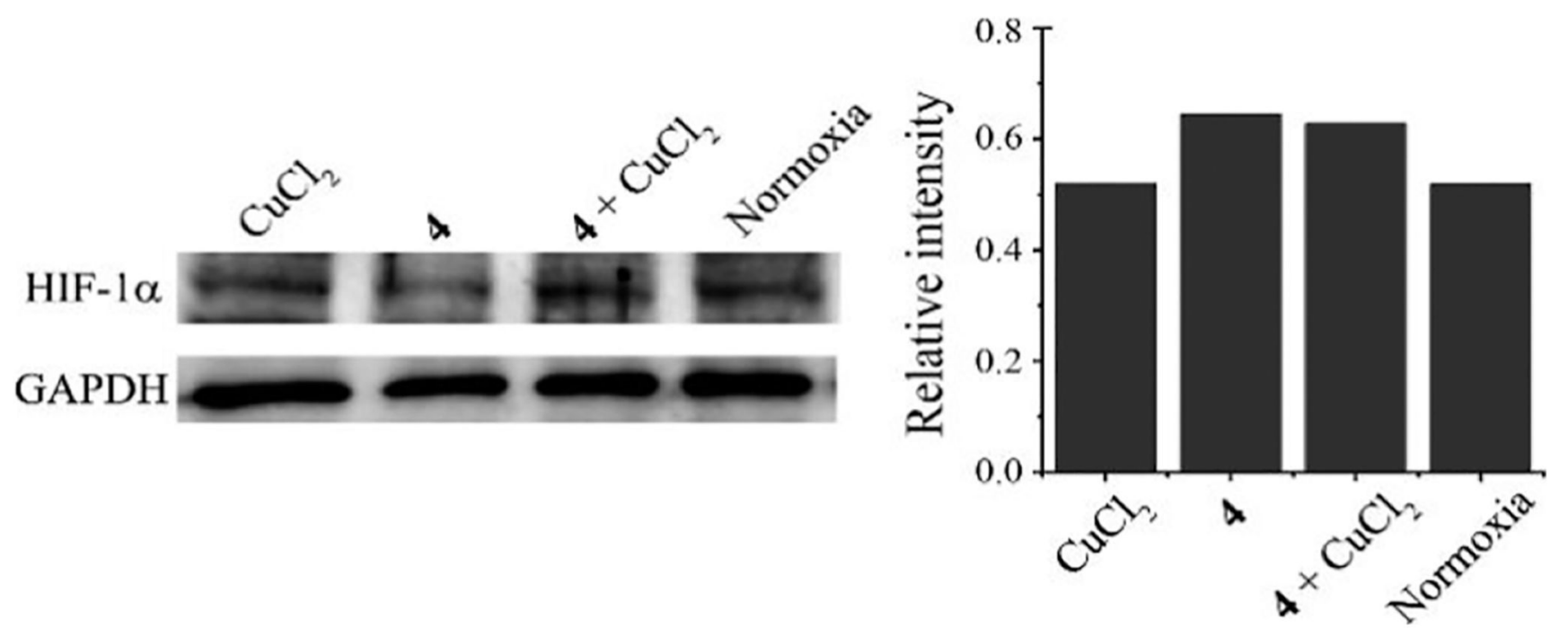

Figure 7.

Levels of HIF-1 $a$ in a HepG2 immunoblot showing protein levels in response to ruthenium compound $\mathbf{4}$ in the presence or absence of copper. GAPDH is taken as the control. 


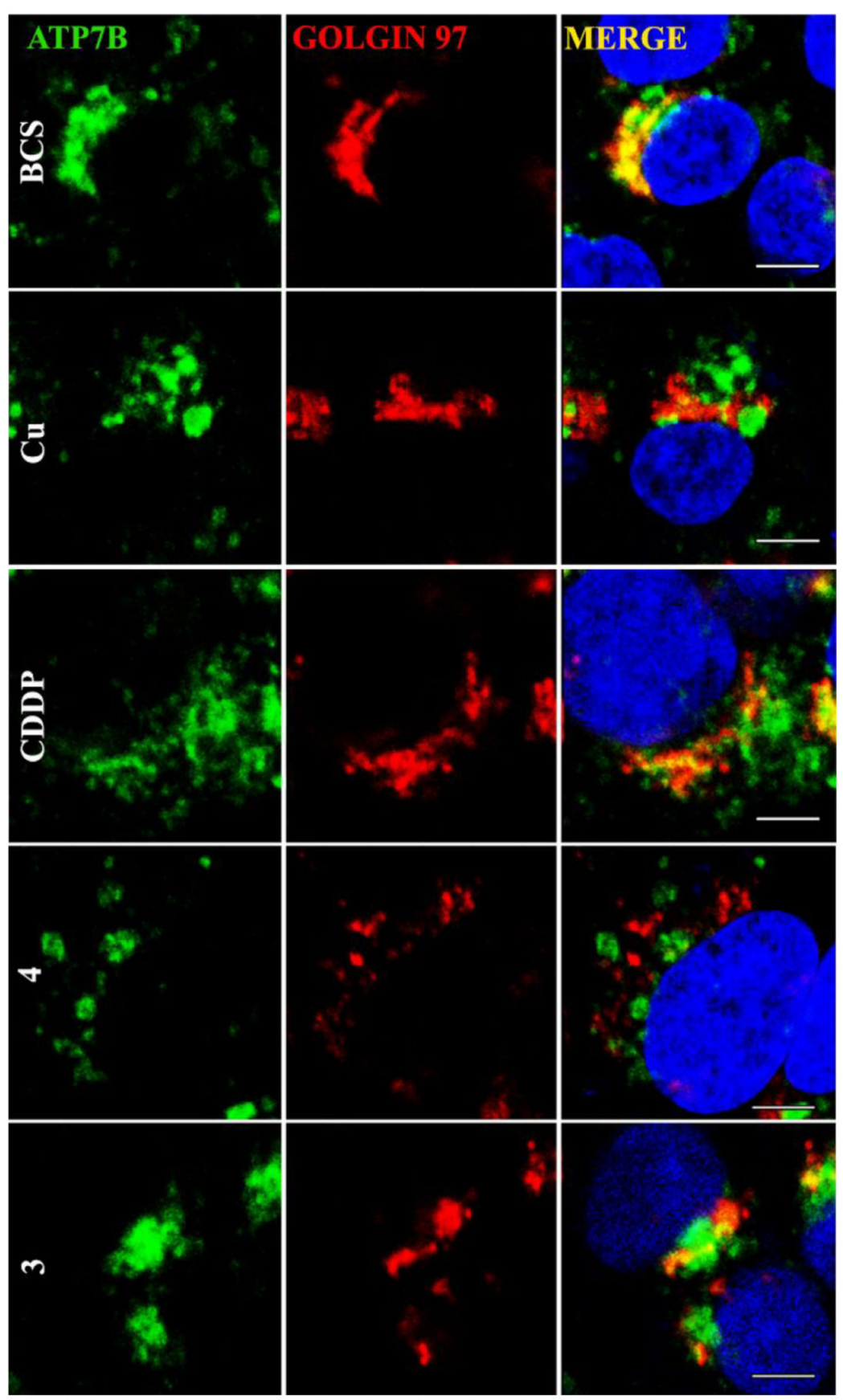

Figure 8.

Effect of ruthenium compounds on ATP7B transport. Colocalization of ATP7B (green) and the TGN (red) in response to ruthenium complexes (3 and 4), CDDP, copper, and disodium bathophenanthrolinedisulfonate (BCS). See Figure S24 for large-field images and for complexes 6 and 7. The bar represents $5 \mu \mathrm{m}$. 


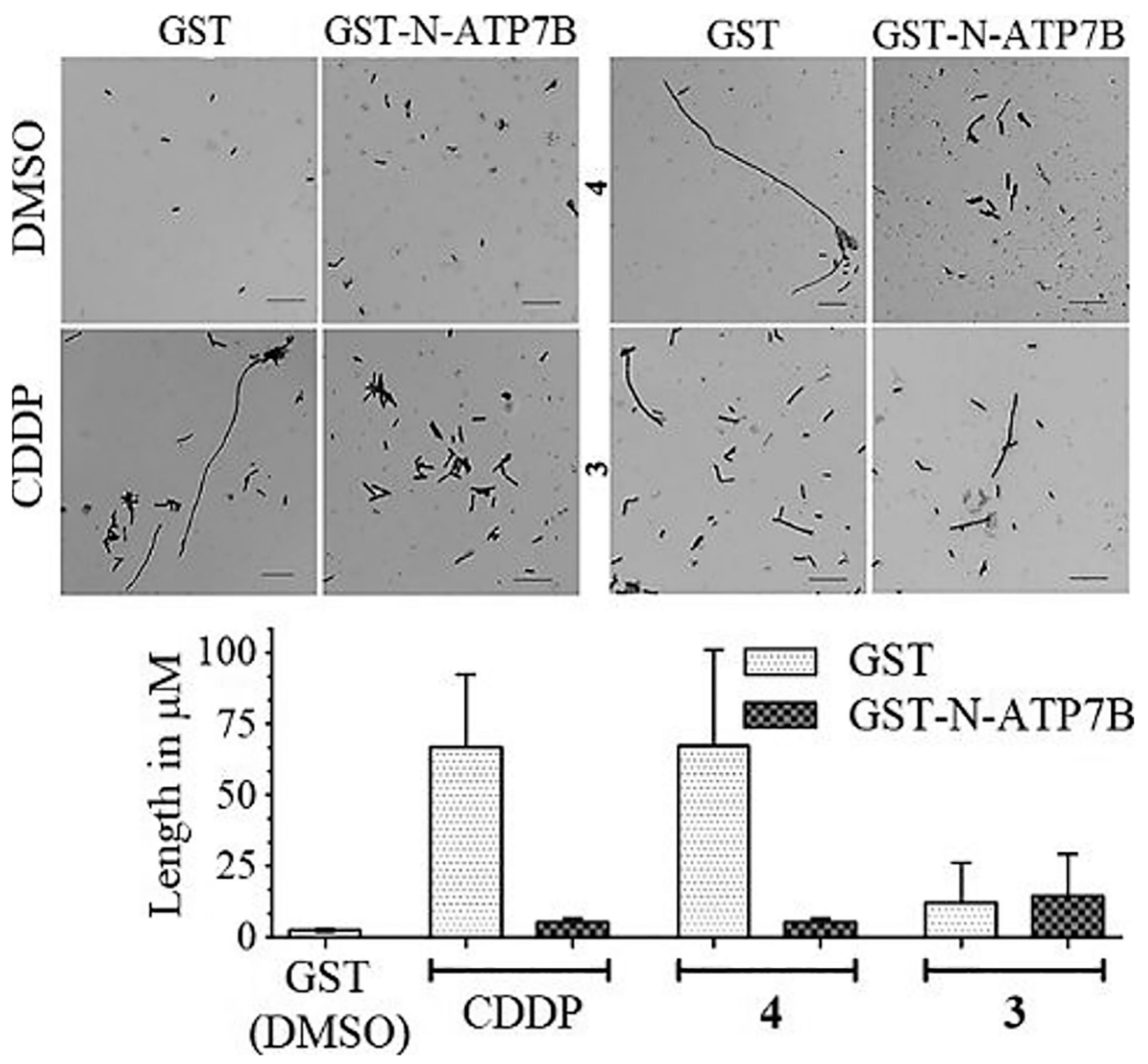

Figure 9.

Bacterial length as a function of the stress induced by ruthenium complexes. Bacteriaexpressing GST-N-ATP7B or GST was subjected to treatment by ruthenium complexes (3 and 4), and CDDP and bacterial length alterations were recorded. The bar represents $10 \mu \mathrm{m}$. (Large images are provided in Figure S25.) 

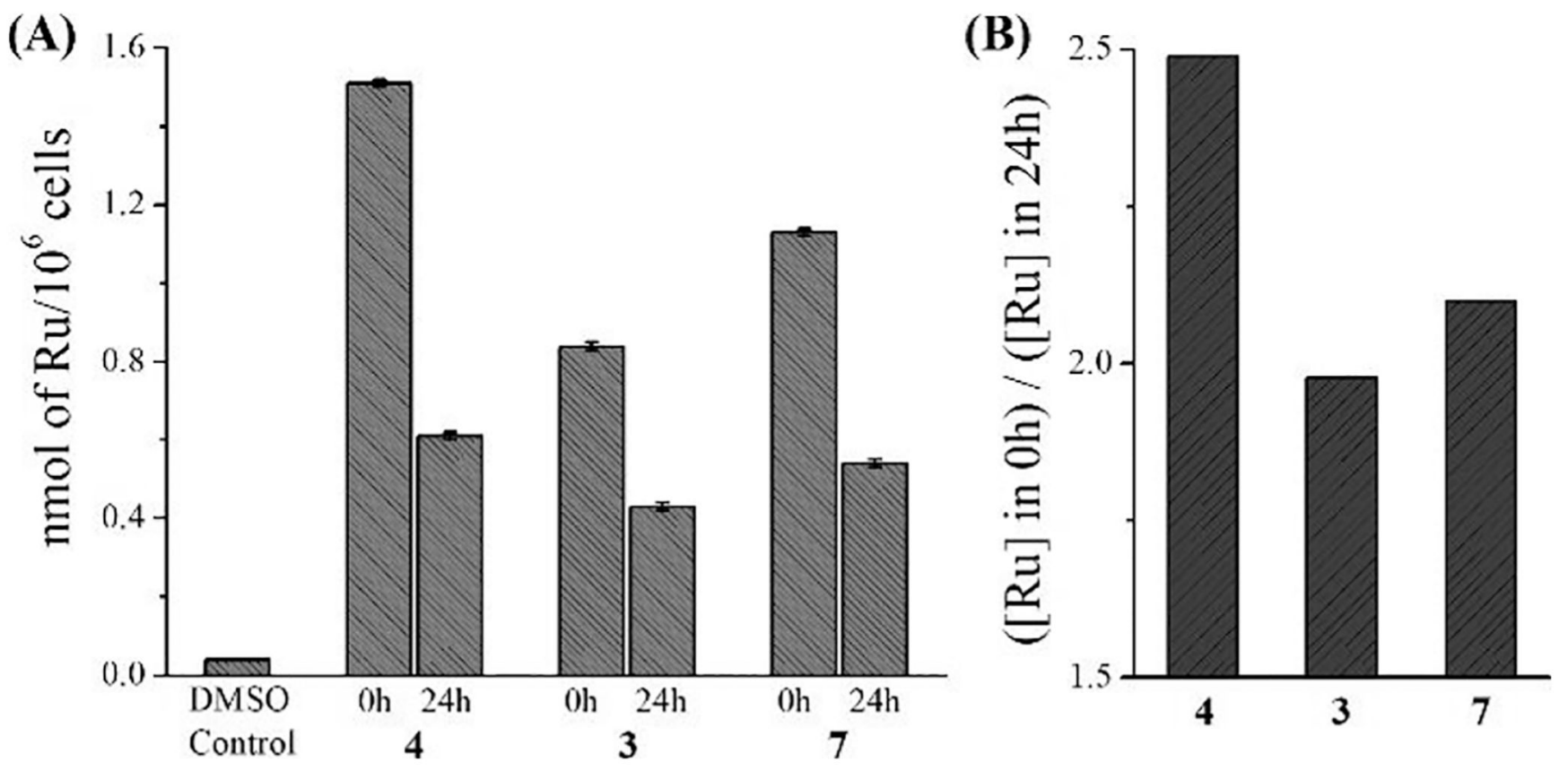

Figure 10.

Total cellular ruthenium content measured at two intervals of time: after immediate removal and after $24 \mathrm{~h}$ for complexes 3, 4, and 7. The total drug treatment time was $4 \mathrm{~h}$ at $37{ }^{\circ} \mathrm{C}$, and the cells used were HepG2. (A) Plot of the ruthenium content in cells after 0 and $24 \mathrm{~h}$ of drug removal measured by ICP-MS. (B) Ratio of the cellular ruthenium concentration showing that the retention order for $\mathbf{3}$ and $\mathbf{7}$ is quite a bit higher than $\mathbf{4}$. 
Table 1

Cytotoxicity Profile of Complexes 1-7 under Normoxic Condition in Comparison to Cisplatin

\begin{tabular}{lccc}
\hline & \multicolumn{3}{c}{$\mathbf{I C}_{\mathbf{5 0}} \pm \mathbf{S D}^{\boldsymbol{a}}(\boldsymbol{\mu M})$} \\
\cline { 2 - 4 } complex & HepG2 & MiaPaCa-2 & MDA-MB-231 \\
\hline $\mathbf{1}$ & $6 \pm 1$ & $7 \pm 1$ & $8.5 \pm 0.5$ \\
$\mathbf{2}$ & $14.6 \pm 1.1$ & $9.5 \pm 0.5$ & $8.5 \pm 0.2$ \\
$\mathbf{3}$ & $14.8 \pm 1.1$ & $7.7 \pm 0.5$ & $7.5 \pm 0.3$ \\
$\mathbf{4}$ & $8 \pm 1$ & $10 \pm 1$ & $9.7 \pm 0.2$ \\
$\mathbf{5}$ & $5.3 \pm 0.4$ & $6.7 \pm 0.5$ & $5.6 \pm 0.2$ \\
$\mathbf{6}$ & $6.1 \pm 0.2$ & $11.4 \pm 0.2$ & $10.2 \pm 0.2$ \\
$\mathbf{7}^{b}$ & $1.03 \pm 0.24$ & $1.34 \pm 0.08$ & $1.64 \pm 0.18$ \\
$\mathrm{CDDP}^{c}$ & $14.3 \pm 1$ & $31.8 \pm 5$ & $37.2 \pm 2.5$ \\
\hline
\end{tabular}

${ }^{a}$ SD: standard deviation.

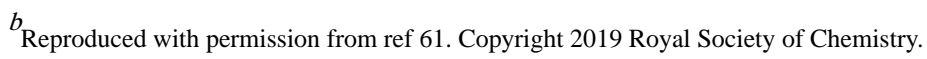

${ }^{c}$ CDDP, cisplatin. Representative fitting plots provided in Figures S26-S29. 